NISTIR 7411

\title{
The Architecture Development Facilitator (ADF) First year report
}

\author{
Steven J. Fenves \\ Eswaran (Sub) Subrahmanian \\ Puja Goyal \\ Jean-Cyrus Angbo \\ Faouzi Daoud \\ Ram D. Sriram
}




\title{
The Architecture Development Facilitator (ADF) First year report
}

\author{
Steven J. Fenves \\ Eswaran (Sub) Subrahmanian \\ Puja Goyal \\ Jean-Cyrus Angbo \\ Faouzi Daoud \\ Ram D. Sriram
}

March, 2007 


\section{ABSTRACT}

This document serves as the summary report on the first year's progress on the Architecture Development Facilitator (ADF) project covering the activities from December 15, 2005, to December 15, 2006. The ADF is intended to assist the Office of Network Coordinator for Health Information Technology (ONC) of the Department of Health and Human Services (HHS) and its agents in the deployment of the Nationwide Health Information Network (NHIN). ADF will serve as the repository of a set of predefined compatible health care IT components, called artifacts, which can then be combined to design, configure and deploy a large variety of health care IT system architectures. The design of ADF responds to the evolving nature of the NHIN by making absolutely no assumptions about the upper levels of the NHIN architecture and by not imposing any constraints on the architecture.

An artifact is defined in ADF as either: (a) a service or system component of NHIN (service artifact) or (b) a unit of information interchanged between service artifacts (information unit artifact). Artifacts are represented in the ADF by a generic template applicable to all artifact types, type-specific template extensions for each type, and by the relationships between the artifacts. An example of the representation is presented in terms of the harmonized use cases released by the ONC. A sampling of distinct network architectures that may be configured from the sample set of artifacts is presented for illustrative purposes.

Initial thoughts are summarized on a number of architectural issues considered during the past year that have not yet been fully developed, as well as the directions for the work we expect to undertake in the second year of the project.

\section{Keywords}

Health care networks; network architecture; bottom-up design; metamodeling. 


\section{TABLE OF CONTENTS}

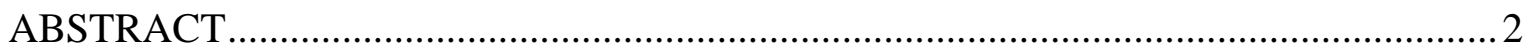

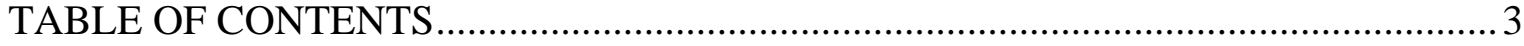

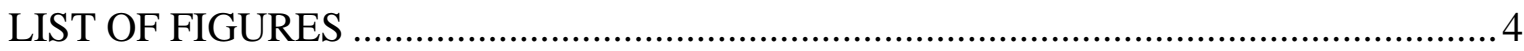

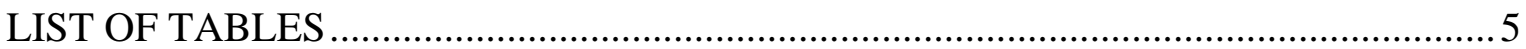

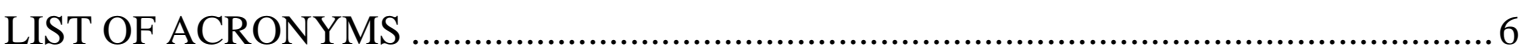

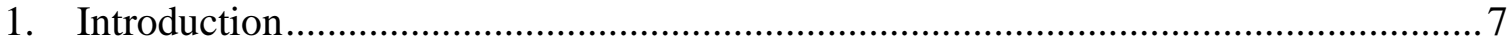

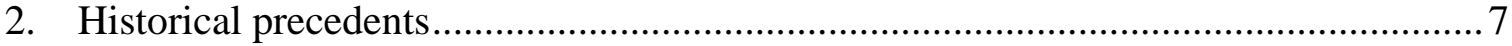

3. The structure of NHIN and the role of ADF ......................................................... 7

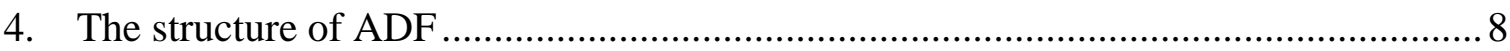

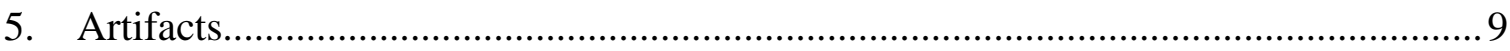

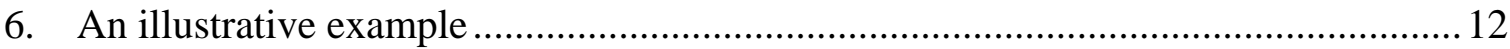

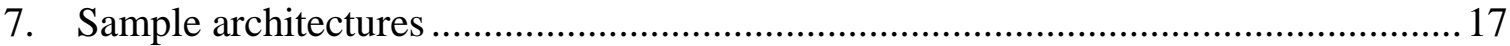

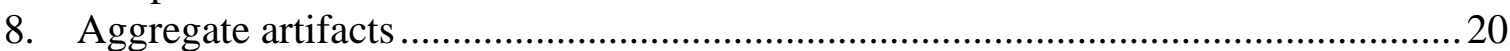

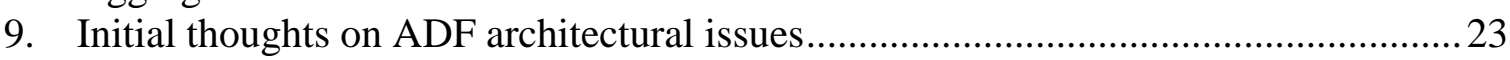

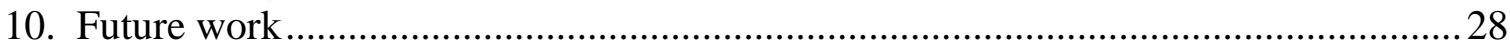

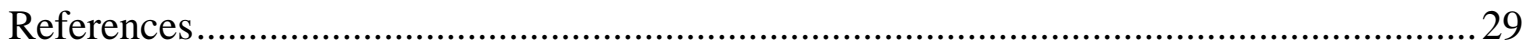

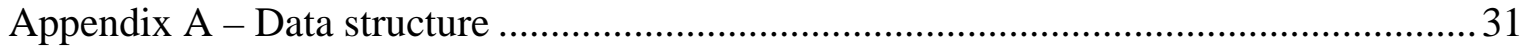

Appendix B - Correspondence to Use Cases ..................... Error! Bookmark not defined.

Appendix C - Comparison of architectures ............................................................. 48 


\section{LIST OF FIGURES}

Figure 1. Network of artifact interactions - laboratory result reporting................................. 15

Figure 2. Combined network of artifact interactions - three use cases ................................. 17

Figure 3a. Fully centralized architecture ........................................................................... 18

Figure 3b. Centralized architecture ........................................................................... 19

Figure 3c. Architecture with centralized IT services .................................................... 19

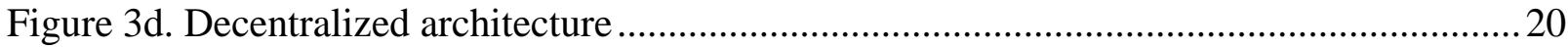

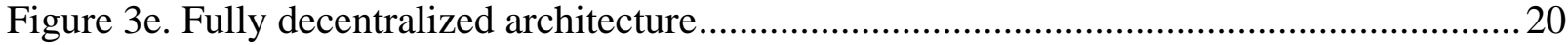

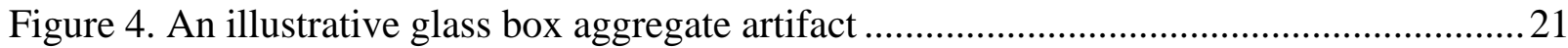

Figure 5. An illustrative black box aggregate artifact......................................................... 22

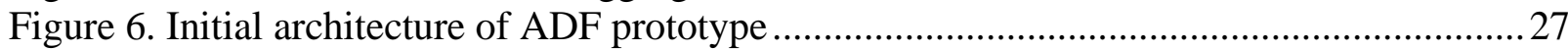

ADF report $\quad 4$ 


\section{LIST OF TABLES}

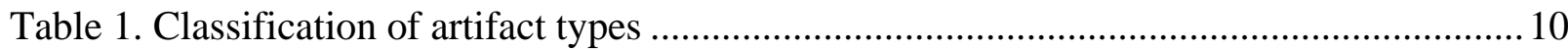

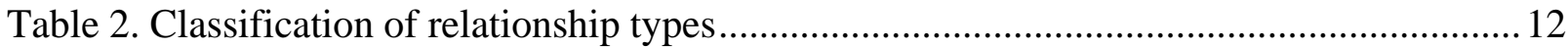

Table 3a. Electronic Health Record Use Case service artifacts............................................. 13

Table 3b. Electronic Health Record Use Case information unit artifacts................................ 14

Table 3c. Bio-Surveillance Use Case service artifacts ...................................................... 15

Table 3d. Bio-Surveillance Use Case information unit artifacts .......................................... 15

Table 3e. Consumer Empowerment Use Case service artifacts ........................................... 16

Table 3f. Consumer Empowerment Use Case information unit artifacts .............................. 16

Table 4. Generalized architectures................................................................................ 18

Table 5. Classification of message artifacts.................................................................. 22

ADF report $\quad 5$ 


\section{LIST OF ACRONYMS}

\begin{tabular}{|l|l|}
\hline ADF & Architecture Development Facilitator \\
\hline CCHIT & Certification Commission for Health Information Technology \\
\hline CDO & Care delivery organization \\
\hline EHR & Electronic Health Records \\
\hline EMR & Electronic medical record system \\
\hline FHA & Federal Health Architecture \\
\hline HHS & Department of Health and Human Services \\
\hline HITSP & Healthcare Information Technology Standards Panel \\
\hline LIS & Laboratory information system \\
\hline METIS & An Enterprise Architecture (EA) platform \\
\hline MPI & Master Person/Patient Index \\
\hline NCVHS & National Committee on Vital and Health Statistics \\
\hline NHIN & Nationwide Health Information Network \\
\hline ONC & Office of Network Coordinator for Health Information Technology \\
\hline PHA & Public health agency \\
\hline PHR & Patient health record system \\
\hline RLS & Record locator service \\
\hline
\end{tabular}




\section{Introduction}

This document serves as the summary report on the first year's progress on the Architecture Development Facilitator (ADF) project for the Office of the Network Coordinator for Health Information Technology (ONC) in the Department of Health and Human Services (HHS), covering the activities from December 15, 2005, to December 15, 2006.

Briefly, the ADF is intended to serve as the repository of a set of predefined compatible health care IT components, called artifacts, which can then be combined to design, configure and deploy a large variety of health care IT system architectures.

\section{Historical precedents}

The concept of bottom-up construction from compatible plug-and-play components being developed by the ONC in HSS and facilitated by the ADF may be novel in IT system design, but it has analogs in a number of other fields.

In manufacturing, the concept was started in the first half of the $19^{\text {th }}$ century by Samuel Colt and Cyrus McCormick with their quest for interchangeable components for revolvers and reapers, respectively. Geared towards mass production in its first 150 years, by the end of the $20^{\text {th }}$ century the concept, variously renamed “agile manufacturing," "product families," "mass customization" and "economical batch size of one," became widely used for the production of virtually unique assemblies out of a set of predefined components. Complex medical devices, such as Computer Tomography (CT) and Nuclear Resonance (NR) scanners, illustrate the great variety of custom systems configured out of a repertoire of compatible components.

In a different analogy, the practice of architecture for buildings is often viewed as the manipulation of space, volume, texture, light, shadow, and abstract elements in order to achieve pleasing aesthetics. This constructive phase of architecture is preceded by another phase, called programming, where the user requirements for the various functional spaces are compiled without regard to the spatial relationships among the spaces, except for some abstract measures of proximity between the spaces. The architectural designer then composes the spatial design out of these predefined functional components. The architectural dictum "form follows function," attributed to the architect Louis Henri Sullivan, emphasizes that the overall form of a building results from satisfying the functional requirements of its components, rather than from some other source, such as historical precedent or style.

\section{The structure of NHIN and the role of ADF}

As implied by its name, the Architecture Development Facilitator is intended to assist the ONC)and its agents in the deployment of the NHIN (1).

The design of the ADF is based on the following observations: 
- As was the case of the Internet, the configuration and final detailed architecture of NHIN will not be fully determined by the time the first set of its component networks is deployed;

- Again, similarly to the Internet, the initial configuration and architecture of NHIN will be subject major revisions and changes as the network evolves from initial pilot systems of limited geographic and functional scope to successively broader coverage with more and more intimate interconnections;

- However, component networks of NHIN, once fielded, must appear to their users as unchanged in function and interactions even as they are integrated or interconnected into larger networks;

- The components out of which NHIN will be constructed need to be highly modular, so that the components, individually or as part of larger networks, are readily replaceable in response to new healthcare needs, policies and standards, new enabling information and communication technologies as well as new administrative structures and business organizations.

The design of ADF responds to the above imperatives by making absolutely no assumptions about the upper levels of the NHIN architecture and by not imposing any constraints on these architectural levels.

\section{The structure of ADF}

Rather than treating the design of the NHIN architecture in the "traditional" top-down fashion, ADF is dedicated to a strictly bottom-up approach.

The principal element of the ADF is a repository of:

- Predefined and mutually compatible components, henceforth called artifacts, which can then be combined to configure and deploy a large variety of health care IT system architectures for NHIN or any of its subnetworks; and

- Documentation related to these artifacts, including but not limited to: requirements, use cases, conformance testing requirements, functional specifications, standards and the interrelationships between the artifacts, requirements, standards and conformance tests.

Additional elements of ADF provide:

- Visualization facilities for navigating among the artifacts in the repository, the interrelationships between these artifacts, and other relevant information for the purpose of presentations to decision makers and other public and elected officials;

- Frameworks for maintaining all information pertaining to standards governing the NHIN components and their interactions, as well to conformance testing requirements, procedures and results for the components and applicable standards in the repository;

- Eventually, public commentary management facilities so as to provide a framework for collecting and aggregating public comments on the components of the NHIN; and

- Eventually, a framework for a versatile testbed where new artifact prototypes can be tested/simulated within the ADF, surrounded by virtual interacting artifacts, or the new artifact prototypes can be tested/simulated remotely in their actual intended setting with virtual interacting artifacts supplied from the ADF. 


\section{Artifacts}

\subsection{Definition}

An operational definition of artifact is that an artifact is either: (a) a service or system component of NHIN (service artifact) or (b) a unit of information interchanged between service artifacts (information unit artifact).

The initial list of artifacts is shown in hierarchical form in Table 1. The indentations in the table represent the multilevel classification of artifact types. Consistent with the design philosophy of the ADF presented above, the list of artifacts is open ended and expected to grow. The initial list was compiled from suggestions by NHIN and Federal Health Architecture (FHA) personnel and various NHIN documents, notably the various vendor presentations at the NHIN Kick-off Meeting on January 18, 2006 (2), and the Functional Requirement Aggregation spreadsheet dated June 27, 2006 (3).

In terms of the classification of artifacts shown in Table 1, ADF itself is a service, more specifically a repository service. In the following, the expression "stored in ADF" is shorthand for "stored in the repository accessed by ADF."

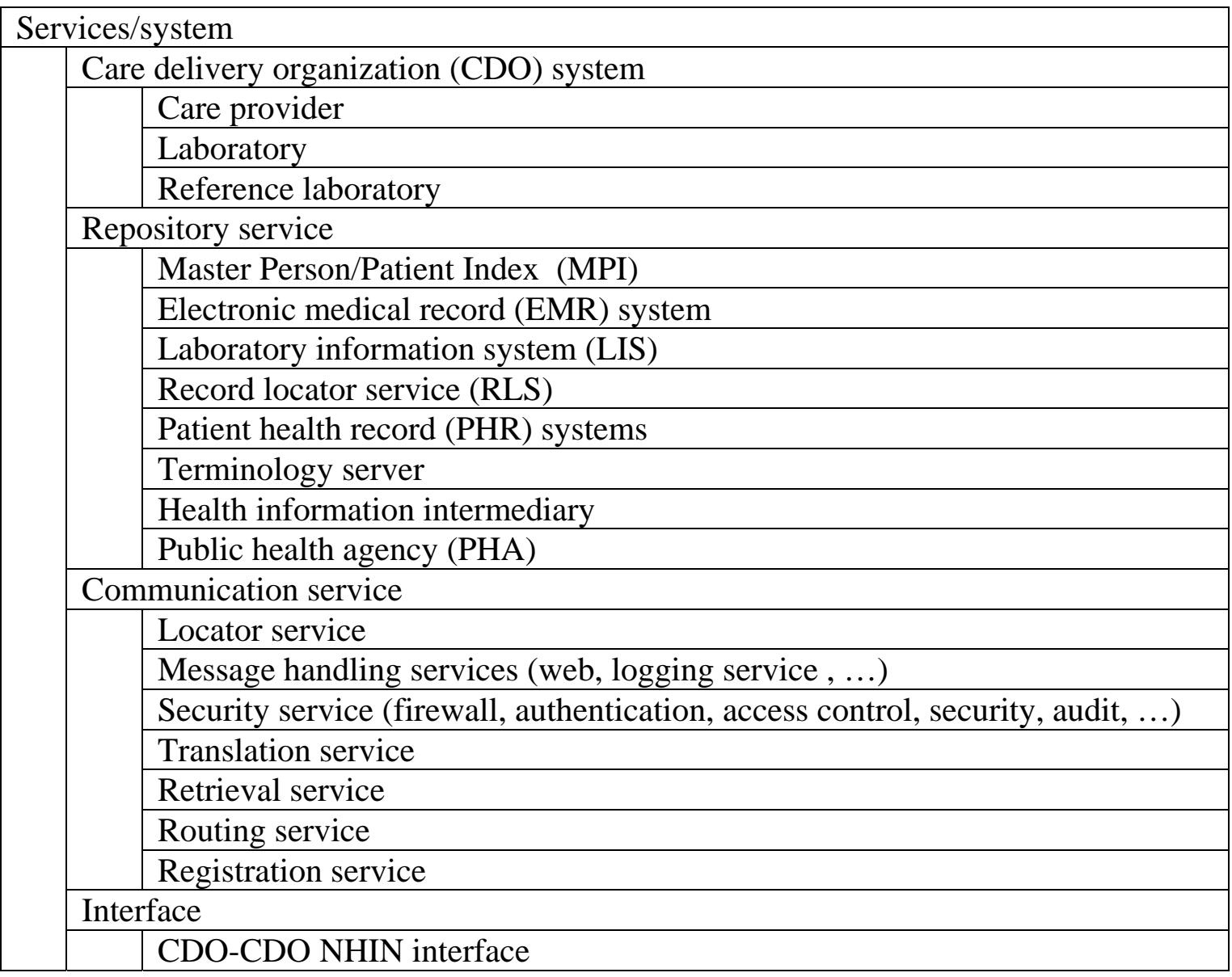




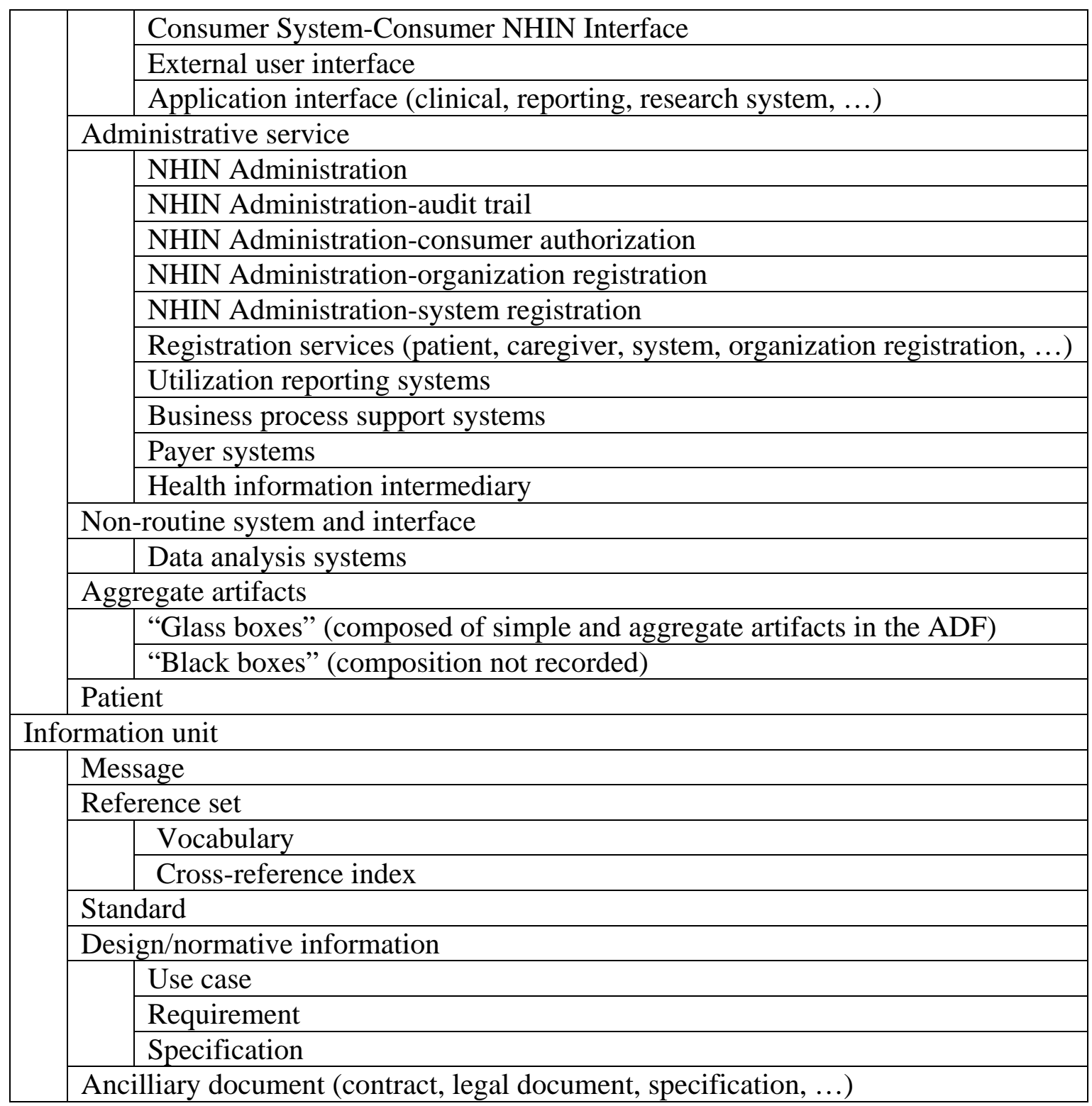

Table 1. Classification of artifact types

\subsection{Representation of artifacts in ADF}

Meta-data are associated with all artifacts in a generic template applicable to all artifact types and in type-specific template extensions for each type.

Services and systems are represented in ADF by templates, listing:

- Protocol describing the service (pre- and post-conditions, exception and error handling procedures, etc.)

- Input data;

- Controls (authorizations, etc.); 
- Output data; and

- Output signals (error messages, etc.).

Inputs, controls, outputs and signals are grouped into information unit artifacts (messages), described below. Ideally, the representation of a service's protocol should be detailed enough to simulate the service's behavior for purposes of conformance testing.

Repositories are represented by two templates: (a) a service template, similar to the one described above, that describes how the repository operates as a service; and (b) an information unit template describing the contents of a typical (or prototypical) unit of information in the repository. The actual content of a repository will never be stored in ADF.

Communication, interfaces, administrative services, and non-routine systems and interfaces are represented by templates of their behavior, suitable for conformance testing.

The detailed representation of aggregate artifacts is presented in Section 6 below.

Some services, particularly message-handling, translation and retrieval services may further be represented in ADF as implementation-dependent alternative templates. Initial thoughts on their representation are given in Section 9.

Patients are represented by the minimal set of attributes needed for communication and interaction with the other ADF artifacts. For purposes of conformance testing, sets of instances of synthetic "patients" may be stored in the repository.

Messages are represented by templates specifying their information contents; the templates also define the appropriate acknowledgement messages and/or error signals. Some message types that may conform to several standards or conventions may further be represented in ADF as implementation-dependent alternative templates. For purposes of conformance testing, sets of instances of synthetic messages may be stored in the repository.

Anciliary documents are represented by templates specifying their information contents. The contents of some key documents may be stored in the ADF.

Reference sets are represented by templates specifying their information contents as well as by access paths to their contents. The contents of vocabularies for some limited bounded terminologies may be stored in the ADF.

Standards are similarly represented by their templates as well as by access paths to their contents. The contents of some limited frequently used standards may be stored in the ADF.

Design and other normative data are generally stored directly in the ADF.

Details of the current data structure for representing artifacts are given in Appendix A. 


\subsection{Relationships}

ADF deals with the relationships among artifacts presented in Table 2 in a hierarchical format.

\begin{tabular}{|l|l|}
\hline Structural relationships \\
\cline { 2 - 3 } & is_a \\
\cline { 2 - 3 } & part_of/has_parts \\
\cline { 2 - 3 } & version_of/has_versions \\
\cline { 2 - 3 } & application_dependent_version_of/has_application_dependent_versions \\
\hline Configurational & relationships \\
\hline & from/to \\
\cline { 2 - 2 } & source/destination \\
\cline { 2 - 3 } & uses/used_by \\
\cline { 2 - 3 } & references/referred_by \\
\cline { 2 - 2 } & uses_standard/standard_governs \\
\hline Temporal /traceability relationships \\
\hline & precedes/follows \\
\hline
\end{tabular}

Table 2. Classification of relationship types

\section{An illustrative example}

\subsection{Description of example}

This example models the three harmonized use cases dated March 19, 2006, released by the ONC. The terminology used is that of the use cases and may not always agree with the terminology used in the previous section for defining artifacts. A detailed correspondence between the events and actions of the use cases and the message artifacts of ADF is presented in Appendix B.

\subsection{Electronic Health Record Use Case}

First, the "Harmonized Use Case for Electronic Health Records (Laboratory Result Reporting)" is presented $(4,(7,(10)$.

The following departures have been made for the March 2006 version of the use case:

- Only the events and actions included in the Healthcare Information Technology Standards Panel (HITSP) report have been used, on the assumption that the HITSP task force had eliminated actions that do not have standardization and communication implications;

- Event 3.2.4.0 "View results using another clinical data system (non-EHR system)" has been eliminated; the event is treated the same way as the interaction with an Electronic Health Record (EHR) system;

- Actions internal to a service (that is, actions not involving a transaction with another participant) have been eliminated; 
- Actions that send, receive, or acknowledge a message have not been separately identified; as stated above, all message artifacts identify the sender and receiver services and include the acknowledgement message (as well as any error message(s));

- In general, messages representing transactions between participants are associated with use case events, rather than constituent actions of an event. The only exception is Event 3.5.2.0 "Process query to provide laboratory test result location(s)" which comprises three distinct transactions;

- The following transactions not contained in the March version of the use case have been added in order to provide a complete scenario that may eventually be simulated in the ADF:

o care provider identification (to locator)

o laboratory identification (to locator)

0 repository identification (to locator)

o EHR identification (to locator)

0 patient presentation (to care provider)

o EHR request (by care provider)

o EHR delivery (to care provider)

o EHR disclosure (by care provider to patient)

o lab order (from care provider)

0 patient presentation (to laboratory)

o EHR update (by care provider)

o patient update (by care provider)

0 consultation request (by care provider)

o consultation response update (by care provider); the last two transactions have been added to allow for consultation among care providers.

Based on the items presented above, the ADF repository representation of the use case consists of the six service artifacts and the message artifacts presented in Tables 3a and 3b. These artifacts can serve as components or building blocks of any architecture for executing this use case, as illustrated in Section 7.

\begin{tabular}{|c|l|l|}
\hline Code $^{1}$ & \multicolumn{1}{|c|}{ Description } & \multicolumn{1}{c|}{ Artifact type } \\
\hline EHRS1 & Patient & -- \\
\hline EHRS2 & Care provider & Service - CDO \\
\hline EHRS3 & Laboratory & Service - CDO \\
\hline EHRS4 & Locator & Service - Repository - RLS \\
\hline EHRS5 & Repository & Service - Repository - LIS \\
\hline EHRS6 & EHR & Service - Repository - EMR \\
\hline
\end{tabular}

Table 3a. Electronic Health Record Use Case service artifacts

\footnotetext{
${ }^{1}$ The coding scheme is: first two or three letters: use case (EHR for Electronic Health Records; BIO for BioSurveillance; CE for Consumer Empowerment); following letter: artifact supertype (S for Service; I for Information unit); sequence number
} 
The patient and the next four services represent the five stakeholders identified in the entitydriven perspectives discussed in the use case; the sixth service, the EHR), is referenced in the use case.

\begin{tabular}{|c|l|l|l|}
\hline Code & \multicolumn{1}{|c|}{ Description } & \multicolumn{1}{c|}{ From service } & \multicolumn{1}{c|}{ To service } \\
\hline EHRI1 & $\begin{array}{l}\text { care provider } \\
\text { identification }\end{array}$ & care provider & locator \\
\hline EHRI2 & $\begin{array}{l}\text { laboratory } \\
\text { identification }\end{array}$ & laboratory & locator \\
\hline EHRI3 & $\begin{array}{l}\text { repository } \\
\text { identification }\end{array}$ & repository & locator \\
\hline EHRI4 & EHR identification & EHR & locator \\
\hline EHRI5 & patient identification & patient & locator \\
\hline EHRI6 & patient presentation & patient & care provider \\
\hline EHRI7 & EHR request & care provider & EHR \\
\hline EHRI8 & EHR delivery & EHR & care provider \\
\hline EHRI9 & EHR disclosure & care provider & patient \\
\hline EHRI10 & lab order & care provider & laboratory \\
\hline EHRI11 & patient presentation to & patient & laboratory \\
\hline EHRI12 & laboratory & laboratory & repository \\
\hline EHRI13 & lab report & repository & care provider \\
\hline EHRI14 & EHR update & care provider & EHR \\
\hline EHRI15 & patient update & care provider & patient \\
\hline EHRI16 & consultation request & care provider & care provider \\
\hline EHRI17 & consultation response & care provider & care provider \\
\hline & & & \\
\hline
\end{tabular}

Table 3b. Electronic Health Record Use Case information unit artifacts

All artifacts are of type message. The confirming and error message transactions are not shown.

The model is shown graphically as an interaction diagram in Figure $1^{2}$.

Yellow boxes denote the service artifacts and green boxes the message artifacts, the latter identified by their code in the list above. The connector branches are uni-directional, their direction defined by the "from" and "to" services in the table above; however, the superposition of two uni-directional connectors, such as in messages EHRI16 and 17, produces the visual appearance of bi-directional connectors.

\footnotetext{
${ }^{2}$ Formally, the network shown in Figure 1 is a bipartite graph, defined as a special graph where the set of nodes can be divided into two disjoint sets $\mathrm{U}$ and $\mathrm{V}$ such that every branch has one end-point in $\mathrm{U}$ and one end-point in $\mathrm{V}$. The simplest way to think of a bipartite graph is one whose nodes can be colored with two colors (yellow and green in the figure) such that no branch exists between nodes of like colors.
} 


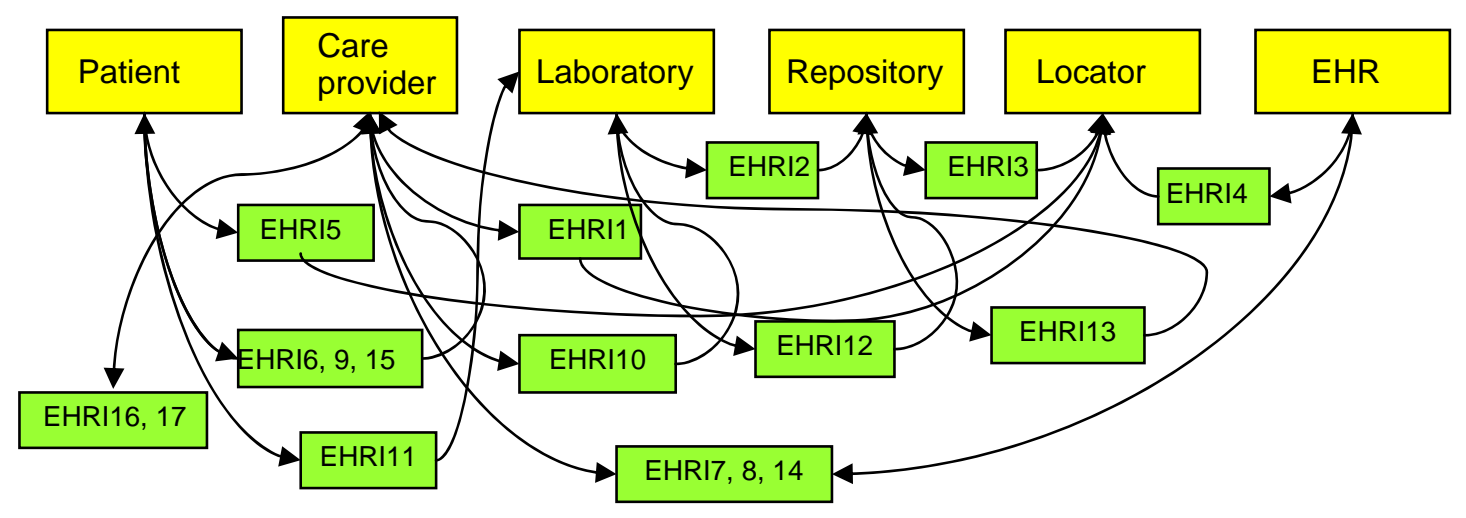

Figure 1. Network of artifact interactions - Laboratory result reporting

These artifacts can be combined into a variety of distinct architectures. An illustrative set of possible generic architectures is presented in Section 7.

\subsection{Bio-Surveillance Use Case}

The representation of the "Bio-Surveillance Harmonized Use Case," using only the "Individual Health Care Delivery Organization" flow path shown in the use case $(5,(8,(11)$, consists of the artifacts shown in Tables 3c and 3d.

\begin{tabular}{|c|l|l|}
\hline Code & \multicolumn{1}{|c|}{ Description } & \multicolumn{1}{c|}{ Artifact type } \\
\hline BIOS1 & Care provider $^{3}$ & Service - CDO \\
\hline BIOS2 & Public health agency & Service - Repository \\
\hline
\end{tabular}

Table 3c. Bio-Surveillance Use Case service artifacts

\begin{tabular}{|l|l|l|l|}
\hline Code & \multicolumn{1}{|c|}{ Description } & \multicolumn{1}{c|}{ From service } & \multicolumn{1}{c|}{ To service } \\
\hline BIOI1 & Filtered data & care provider & care provider \\
\hline BIOI2 & Aggregate data & care provider & care provider \\
\hline BIOI3 & Randomized data & care provider & care provider \\
\hline BIOI4 & Transformed data & care provider & care provider \\
\hline BIOI5 & PHA request & care provider & public health agency \\
\hline BIOI6 & Biohazard report & care provider & public health agency \\
\hline BIOI7 & $\begin{array}{l}\text { Notification to care } \\
\text { providers }\end{array}$ & $\begin{array}{l}\text { public health } \\
\text { agency }\end{array}$ & care provider \\
\hline
\end{tabular}

Table 3d. Bio-Surveillance Use Case information unit artifacts

\footnotetext{
${ }^{3}$ same as EHRS2 - Care provider
} 


\subsection{Consumer Empowerment Use Case}

The representation of the "Consumer Empowerment Harmonized Use Case", combining the three flow scenarios shown in the use case $(6,(9,(12)$, consists of the artifacts shown in Tables 3e and 3f.

\begin{tabular}{|c|l|l|}
\hline Code & \multicolumn{1}{|c|}{ Description } & \multicolumn{1}{c|}{ Artifact type } \\
\hline CES1 & Consumer $^{4}$ & -- \\
\hline CES2 & PHR service provider & Service - Repository -PHR \\
\hline CES3 & Health care provider & Service -- CDO \\
\hline CES4 & $\begin{array}{l}\text { Data or network system } \\
\text { manager }\end{array}$ & $\begin{array}{l}\text { assumed to be } \\
\text { Service - Repository - EHR }\end{array}$ \\
\hline CES5 & EHR $^{6}$ & Service - Repository - EHR \\
\hline
\end{tabular}

Table 3e. Consumer Empowerment Use Case service artifacts

\begin{tabular}{|c|c|c|c|}
\hline Code & Description & From service & To service \\
\hline CEI1 & $\begin{array}{l}\text { PHR service selection } \\
\text { and permissions }\end{array}$ & Consumer & PHR service provider \\
\hline CEI2 & Authenticate to system & Consumer & $\begin{array}{l}\text { Data or network system } \\
\text { manager }\end{array}$ \\
\hline CEI3 & $\begin{array}{l}\text { Registration and } \\
\text { medication data }\end{array}$ & Consumer & PHR service provider \\
\hline CEI4 & $\begin{array}{l}\text { Registration and } \\
\text { medication data }\end{array}$ & $\begin{array}{l}\text { PHR service } \\
\text { provider }\end{array}$ & $\begin{array}{l}\text { Data or network system } \\
\text { manager }\end{array}$ \\
\hline CEI5 & $\begin{array}{l}\text { Registration and } \\
\text { medication data }\end{array}$ & $\begin{array}{l}\text { PHR service } \\
\text { provider }\end{array}$ & Consumer \\
\hline CEI6 & Summary \& history & $\begin{array}{l}\text { PHR service } \\
\text { provider }\end{array}$ & $\begin{array}{l}\text { Data or network system } \\
\text { manager }\end{array}$ \\
\hline CEI7 & $\begin{array}{l}\text { Summary \& history } \\
\text { modification }\end{array}$ & Consumer & PHR service provider \\
\hline CEI8 & $\begin{array}{l}\text { Summary \& history to } \\
\text { health care provider }\end{array}$ & $\begin{array}{l}\text { PHR service } \\
\text { provider }\end{array}$ & Health care provider \\
\hline CEI9 & $\begin{array}{l}\text { summary \& history to } \\
\text { EHR }\end{array}$ & $\begin{array}{l}\text { Health care } \\
\text { provider }\end{array}$ & EHR manager \\
\hline
\end{tabular}

Table 3f. Consumer Empowerment Use Case information unit artifacts

A model combining all the three use cases is shown graphically in Figure 2.

\footnotetext{
${ }^{4}$ same as EHRS1 - Patient

${ }^{5}$ same as EHRS2 - Care provider

${ }^{6}$ same as EHRS6 - EHR
} 


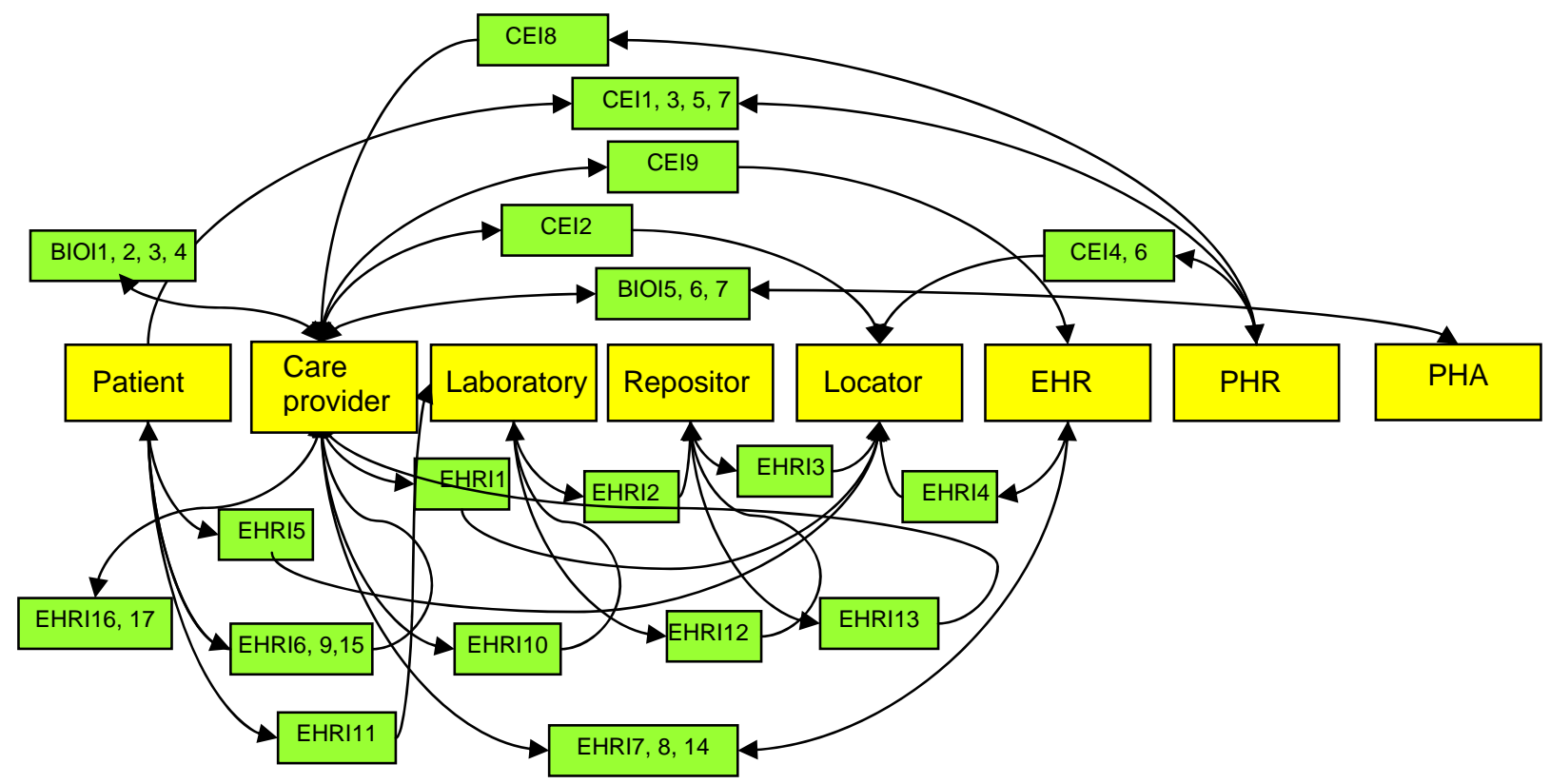

Figure 2. Combined network of artifact interactions - three use cases

\section{Sample architectures}

The artifacts identified in Figure 1 (EHR use case) may be combined into the generalized architectures presented in Table 24 and illustrated in Figures Figure 3a through Figure 3e. The last column of Table 24 shows instances of each architecture extracted from the NHIN contractors' presentations at the January 18, 2006, ONC Kickoff presentations (2). A more direct comparison of the conceptual architectures with the contractors' presentations is shown in Appendix C.

\begin{tabular}{|c|c|c|c|c|}
\hline $\begin{array}{l}\text { Architec- } \\
\text { ture } \\
\text { name }\end{array}$ & Description & $\begin{array}{c}\text { Services } \\
\text { outside }\end{array}$ & $\begin{array}{l}\text { Services } \\
\text { inside }\end{array}$ & $\begin{array}{c}\text { Instances from } \\
\text { Jan } 18 \text { Kickoff } \\
\text { meeting } \\
\text { presentations }\end{array}$ \\
\hline $\begin{array}{c}\text { Fully } \\
\text { centralized }\end{array}$ & $\begin{array}{l}\text { All services, including } \\
\text { care providers, are } \\
\text { concentrated in the core } \\
\text { Health Care Delivery } \\
\text { Organization }\end{array}$ & Patient & $\begin{array}{l}\text { Care } \\
\text { provider } \\
\text { Laboratory } \\
\text { Locator } \\
\text { Repository } \\
\text { EHR } \\
\end{array}$ & $\begin{array}{l}\text { Northrop Grumman } \\
\text { closed entity }\end{array}$ \\
\hline Centralized & $\begin{array}{l}\text { Care providers are } \\
\text { external, but all other } \\
\text { services are concentrated } \\
\text { in the core Health Care } \\
\text { Delivery Organization }\end{array}$ & $\begin{array}{l}\text { Patient } \\
\text { Care } \\
\text { provider }\end{array}$ & $\begin{array}{l}\text { Laboratory } \\
\text { Locator } \\
\text { Repository } \\
\text { EHR }\end{array}$ & $\begin{array}{l}\text { Northrop Grumman } \\
\text { open entity }\end{array}$ \\
\hline Centralized IT & Patient-oriented services & Patient & Locator & Accenture \\
\hline
\end{tabular}




\begin{tabular}{|c|c|c|c|c|}
\hline services & $\begin{array}{l}\text { are external, shared } \\
\text { services are concentrated } \\
\text { in the core Health Care } \\
\text { Delivery Organization }\end{array}$ & $\begin{array}{l}\text { Care } \\
\text { provider } \\
\text { Laboratory }\end{array}$ & $\begin{array}{l}\text { Repository } \\
\text { EHR }\end{array}$ & $\begin{array}{l}\text { CSC } \\
\text { IBM Comm. } 1\end{array}$ \\
\hline Decentralized & $\begin{array}{l}\text { All services and local } \\
\text { data stores are external; } \\
\text { the Regional (or } \\
\text { National) Network } \\
\text { Infrastructure Provider } \\
\text { serves as the shared data } \\
\text { repository }\end{array}$ & $\begin{array}{l}\text { Patient } \\
\text { Care } \\
\text { provider } \\
\text { Laboratory } \\
\text { Repository }\end{array}$ & $\begin{array}{l}\text { Locator } \\
\text { EHR }\end{array}$ & IBM Comm. 2 \\
\hline $\begin{array}{c}\text { Fully } \\
\text { decentralized }\end{array}$ & $\begin{array}{l}\text { All services and data } \\
\text { stores are external; the } \\
\text { only linkage being the } \\
\text { locator serving as the } \\
\text { Regional (or National) } \\
\text { Network Infrastructure } \\
\text { Provider }\end{array}$ & $\begin{array}{l}\text { Patient } \\
\text { Care } \\
\text { provider } \\
\text { Laboratory } \\
\text { Repository } \\
\text { EHR }\end{array}$ & Locator & $\begin{array}{l}\text { IBM Comm. } 3 \\
\text { Northrop Grumman } \\
\text { independent entity }\end{array}$ \\
\hline
\end{tabular}

\section{Table 4. Generalized architectures}

In all the architectures shown it is assumed that the repository and EHR managers are on the same side of the inside-outside divide as the data repositories they manage. However, as can be seen from the table, all of the message artifacts, other than the Patient-to-locator message, will need to be represented in ADF as three implementation-dependent alternative templates for the following three cases:

- $\quad$ services are both inside (no translation or standardization applies);

- sending and receiving services are both outside; and

- $\quad$ services are on opposite sides of the divide.

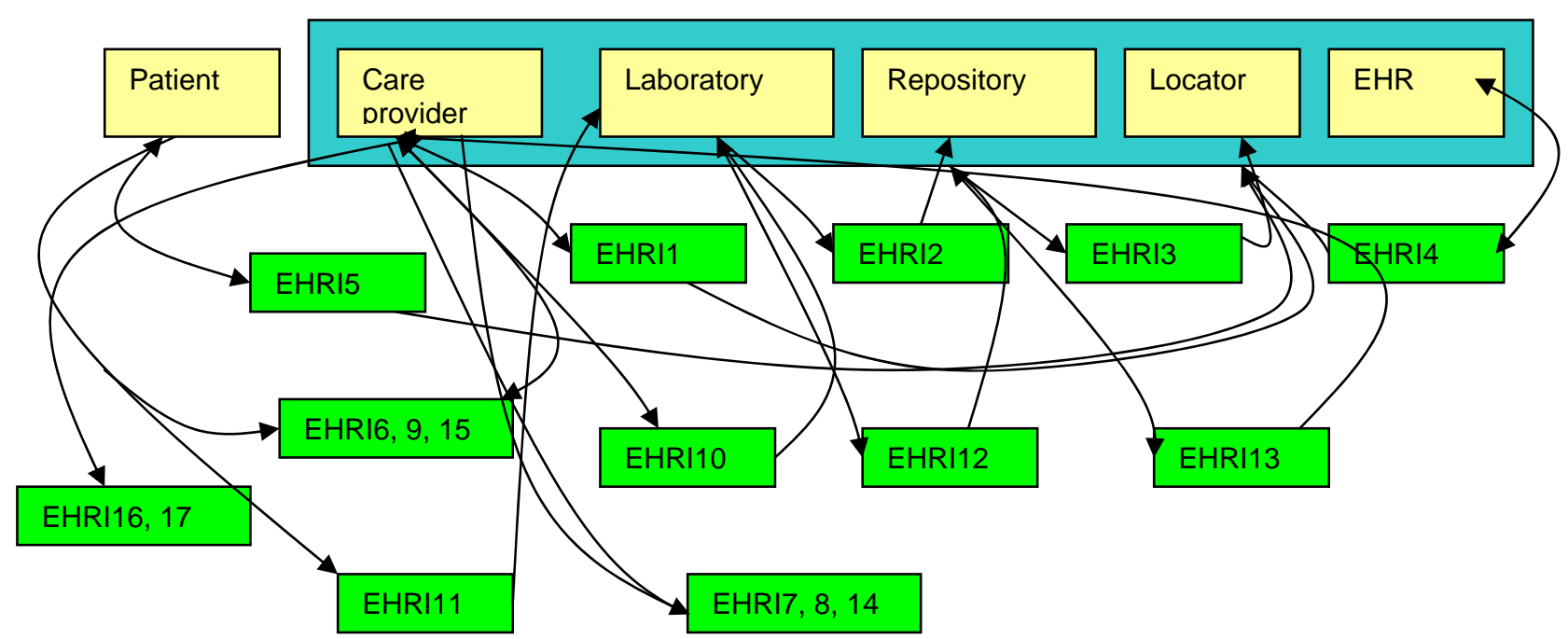

Figure 3a. Fully centralized architecture 


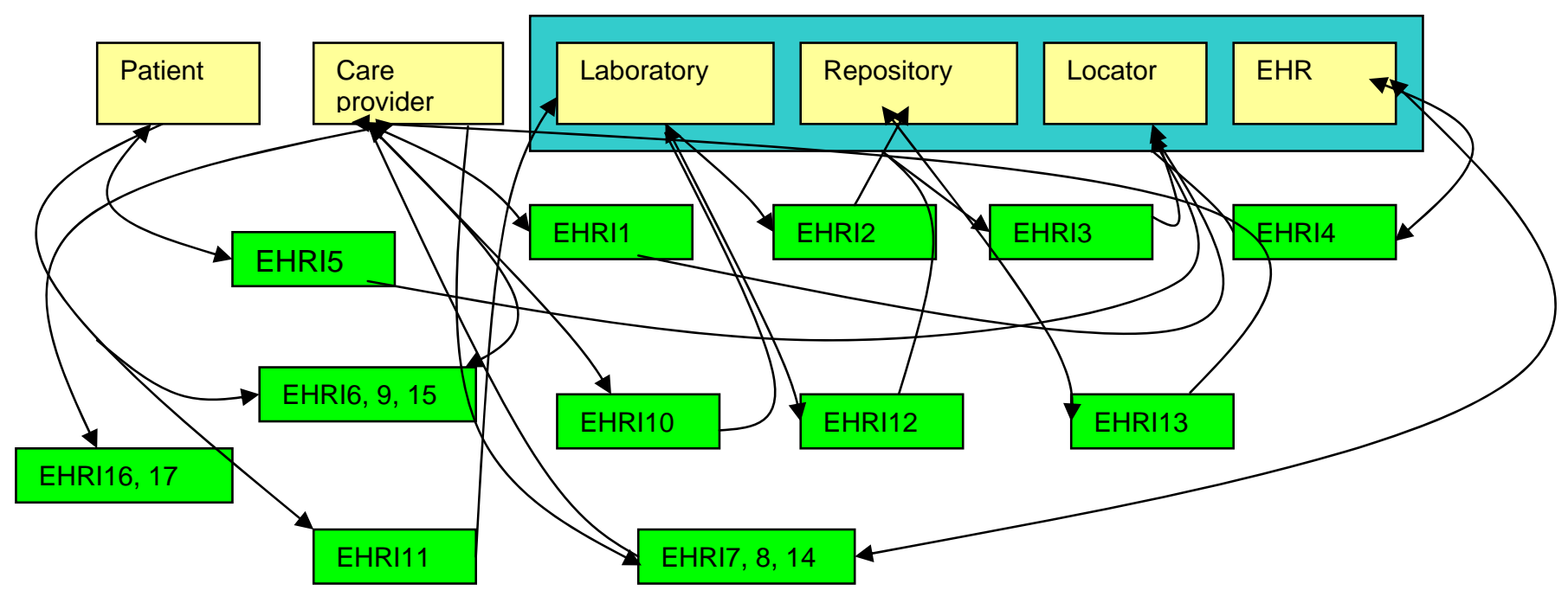

Figure 3b. Centralized architecture

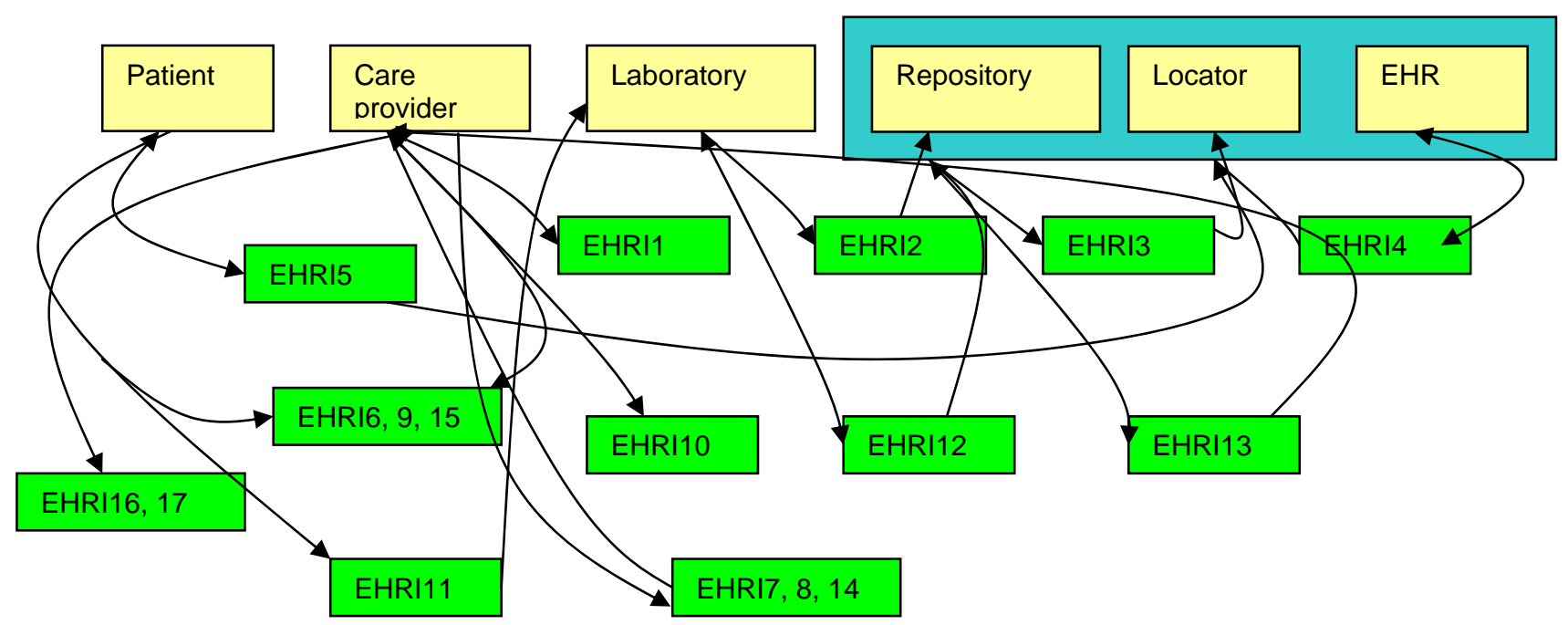

Figure 3c. Architecture with centralized IT services 


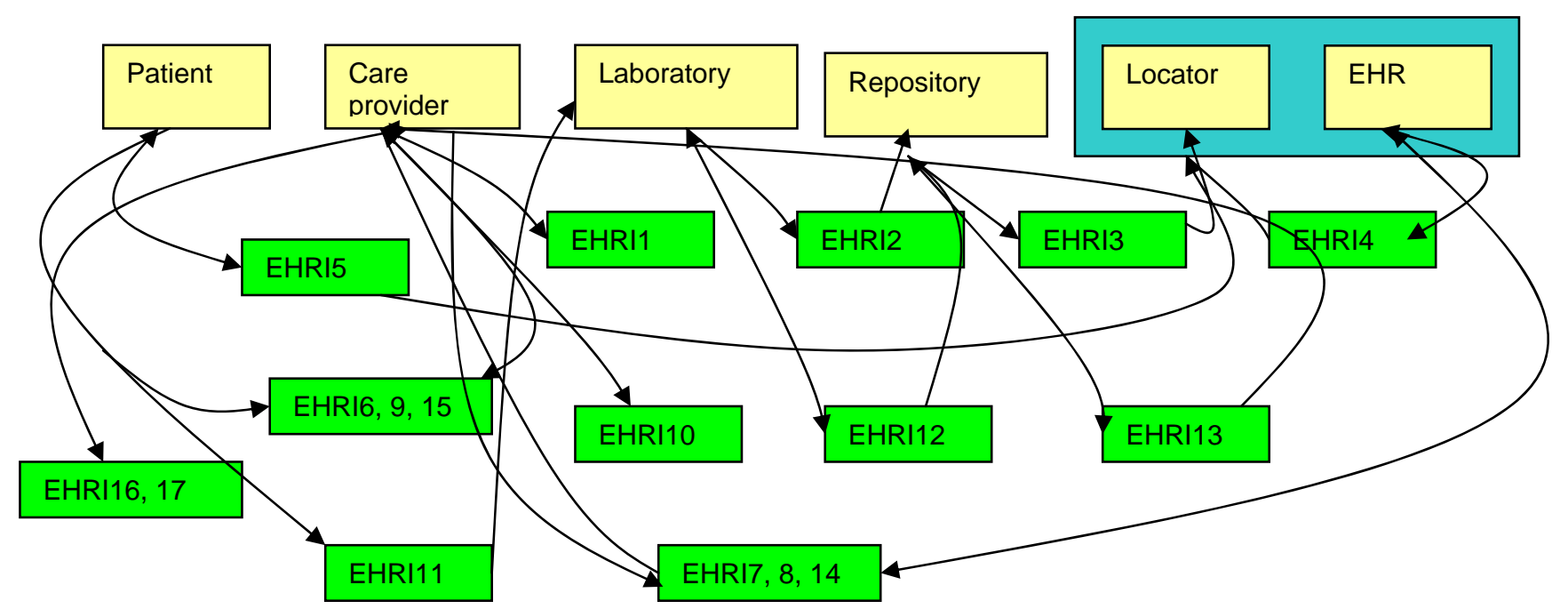

Figure 3d. Decentralized architecture

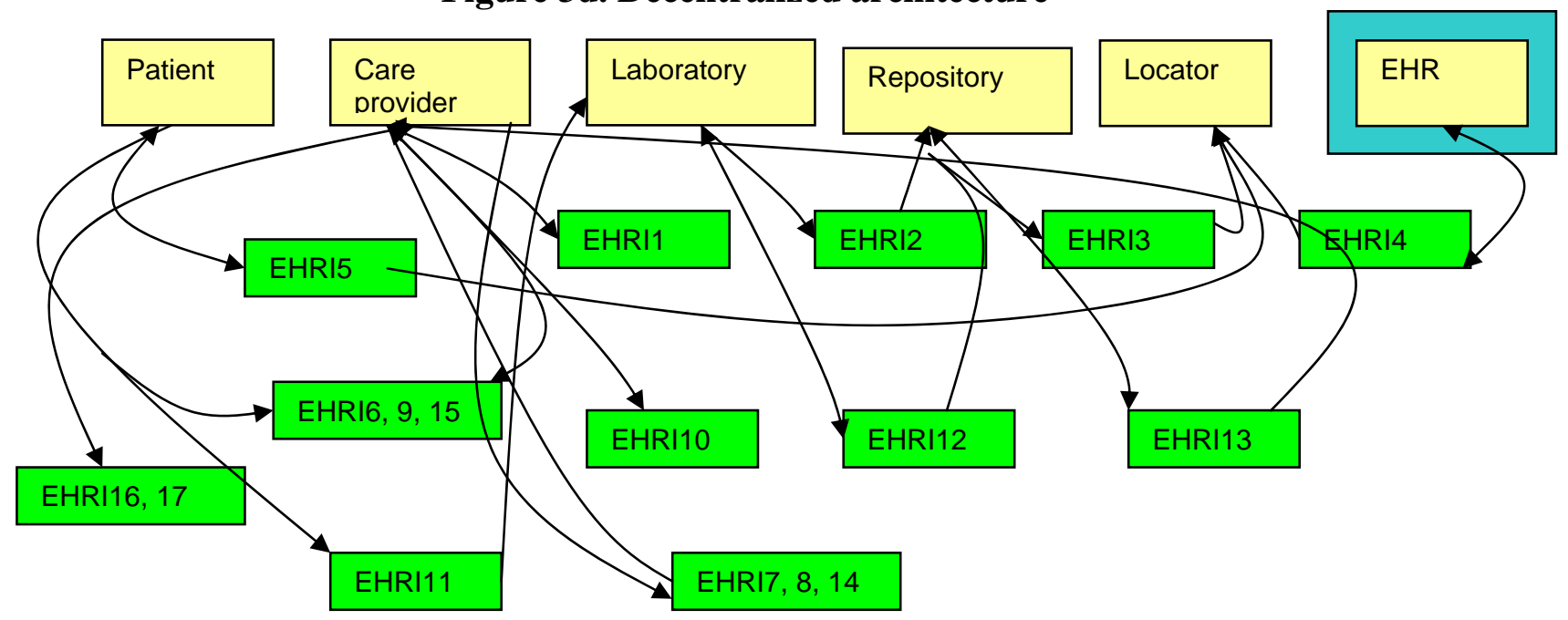

Figure 3e. Fully decentralized architecture

\section{Aggregate artifacts}

ADF supports two types of aggregate service artifacts: "glass boxes" and "black boxes." Glass box aggregate artifacts are composed of artifacts and other aggregate artifacts contained in the ADF. Black box aggregate artifacts are represented as themselves and are not further decomposable.

To illustrate the two types of aggregate artifacts, assume that the centralized IT services of the architecture illustrated in Figure $3 \mathrm{c}$ are to be made into an aggregate artifact, as shown in Figure 4 . The message artifacts, reproduced in the table below, are now classified into three categories:

- inside, if both the "from service" and the "to service" are inside the aggregate artifact; 
- outside, if both the "from service" and the "to service" are outside the aggregate artifact; and

- interface otherwise, i. e., either the "from service" is inside and the "to service" is outside the aggregate artifact or the "from service" is outside and the "to service" is inside the aggregate artifact.

In the table below the messages are classified accordingly. The interface messages are highlighted in red and the inside messages in blue.

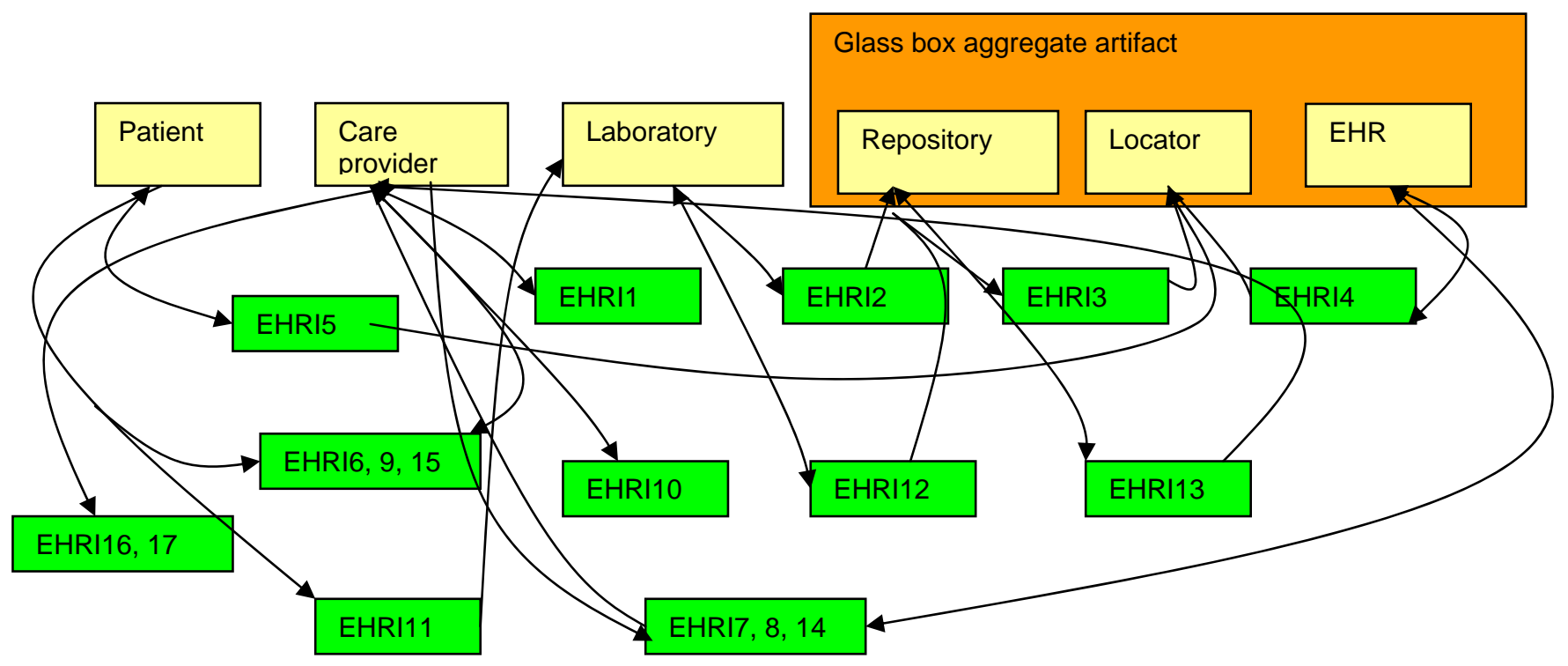

Figure 4. An illustrative glass box aggregate artifact

Figure 4 is the ADF representation of a glass box aggregate artifact: the component artifacts are identified, the inside messages are retained, and the interface messages are linked to the component artifacts.

\begin{tabular}{|l|l|l|c|}
\hline Code & \multicolumn{1}{|c|}{ From service } & \multicolumn{1}{|c|}{ To service } & $\begin{array}{c}\text { Classification of } \\
\text { message artifact }\end{array}$ \\
\hline EHRI1 & care provider & locator & interface \\
\hline EHRI2 & laboratory & locator & interface \\
\hline EHRI3 & repository & locator & inside \\
\hline EHRI4 & EHR & locator & inside \\
\hline EHRI5 & patient & locator & outside \\
\hline EHRI6 & patient & care provider & interface \\
\hline EHRI7 & care provider & EHR & interface \\
\hline EHRI8 & EHR & care provider & outside \\
\hline EHRI9 & care provider & patient & outside \\
\hline EHRI10 & care provider & laboratory & outside \\
\hline EHRI11 & patient & laboratory & interface \\
\hline EHRI12 & laboratory & repository & interface \\
\hline EHRI13 & repository & care provider & interface \\
\hline EHRI14 & care provider & EHR & \\
\hline
\end{tabular}




\begin{tabular}{|l|l|l|l|}
\hline EHRI15 & care provider & patient & outside \\
\hline EHRI16 & care provider & care provider & outside \\
\hline EHRI17 & care provider & care provider & outside \\
\hline
\end{tabular}

Table 5. Classification of message artifacts

By contrast, the representation of the same network as a black box aggregate artifact is shown in Figure 5: the inside messages are not recorded and the interface messages connect to the aggregate artifact at the aggregate artifact's interfaces, illustrated in the figure by blue triangles. Thus, all the internal structure of the aggregate artifact is suppressed.

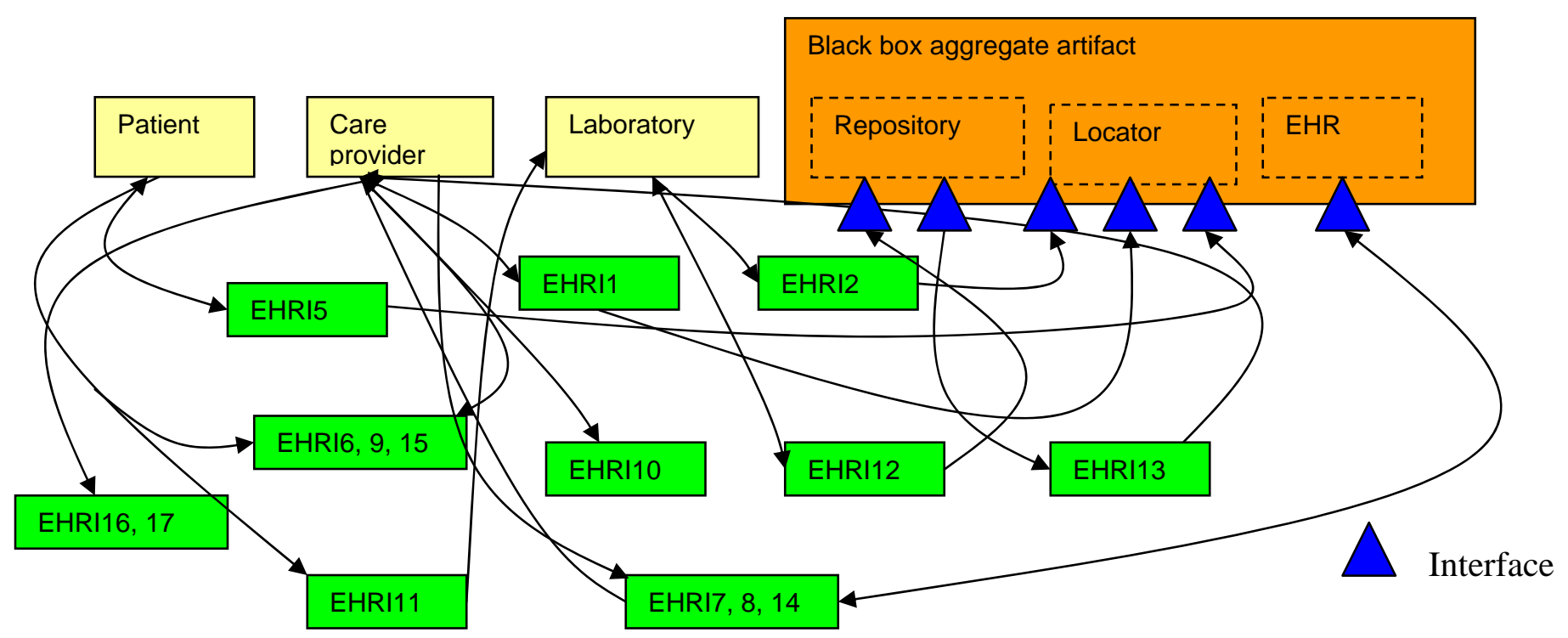

Figure 5. An illustrative black box aggregate artifact

It is anticipated that aggregate artifacts created with the aid of ADF from component artifacts in the ADF repository will become glass box aggregate artifacts. On the other hand, existing networks imported into the ADF from external sources will tend to be stored as black box aggregate artifacts. At the present, we do not plan to implement "make glass box" and "make black box" operations (functions) in the ADF prototype, although the need for these operations may arise in the production version of the ADF. Suffice to say that the "make black box" operation is relatively simple to implement: delete internal messages and transfer the endpoints of interface messages from the constituent artifacts to the aggregate artifact interfaces. The reverse operation, to "make glass box" from a black box aggregate artifact, requires considerable additional information: the location of endpoints of all interface messages and the existence and routing of all inside messages.

Hierarchical or nested aggregate artifacts, that is, aggregate artifacts that have other aggregate artifacts as components, are possible and can be readily represented by the ADF facilities described above, with one qualification:

- glass box aggregate artifacts of any arbitrary level of nesting are possible; 
- lower-level sub-aggregate artifacts of glass boxes can be black boxes; but

- black box aggregate artifacts cannot have sub-aggregates.

\section{Initial thoughts on ADF architectural issues}

In this section, we summarize a number of architectural issues considered during the past year that have not yet been developed to the same extent as the issues discussed above.

\subsection{Representation of implementation-dependent alternatives}

As stated above, many, if not most, message artifacts will have to be represented by several implementation-dependent alternatives. One key determinant of which alternative will be used in a given situation is whether the message artifact connects two services inside the network, outside the network, or across the network boundary. There may be other determinants based on different levels of security and/or privacy, different stages of certification, alternate interface standards or alternate translation services.

The current idea is to have templates for all the alternatives stored in the repository and extract the appropriate alternative for each application. It remains to be seen whether this approach will work or whether, in order to avoid combinatorial problems, a more constructive, modular approach is needed.

\subsection{Representation of standards}

Individual artifacts are currently linked to standards by uses_standard relationships. The specific representation of the standards, and their linkage to the repository maintained by the parallel NIST activity on standards conformance checking, remains to be determined in consultation with that activity. Provisions have already been made to link conformance checking and approval/adoption status to the standards.

\subsection{Representation of use cases}

Use cases are currently the top nodes in the hierarchical metamodel of the ADF. The use cases are linked to the spreadsheets presented in Appendix A. The higher-level metamodel of present and potential use cases being developed for ONC is being coordinated with the ADF model so that eventually the merged metamodel can be stored in the ADF. 


\subsection{Archiving of previously generated networks}

Networks of healthcare information services will be generated from artifacts stored in the ADF. Since the NHIN will be dynamically growing, in possibly unforeseen ways, the ADF will have to retain full information about networks previously generated from ADF artifacts so that truth maintenance and version control can be strictly applied. This will be achieved by storing in the ADF the full specification of the set of artifacts extracted to form each particular network. Thus, for example, if a new version of a standard is issued, all affected artifacts in the repository can be identified through the standard_governs relationship of that standard; the specifications of all derived networks can then be scanned for the presence of affected artifacts.

\subsection{Representation of requirements}

The NHIN functional requirements proposed by National Committee on Vital and Health Statistics (NCVHS) are at the present in a state of flux (13). Furthermore, the requirements are stated as addressing various entities. These entities have not yet been formally related to the artifacts managed by the ADF. A preliminary study shows that the entities are of three types:

- Entities that directly correspond to artifacts, such as "Laboratory";

- Entities that are aggregations of artifacts, such as "Care delivery organizations (CDOs);” or

- Entities that are components of artifacts, such as "CDO-CDO interfaces."

If this classification is found to be generally applicable, the functional requirements can be treated as artifacts in the ADF and linked through the classification to the artifacts, aggregations or components affected. The only requirement on the ADF data structure is that all instances of aggregation and decomposition of artifacts corresponding to the entities addressed be represented in the data hierarchy shown in Table 1 and elaborated in Appendix B. If this proves to be too onerous, a correspondence table between artifacts and entities can be used.

\subsection{Business process implications of ADF}

In principle, the production version of $\mathrm{ADF}$ could be hosted by a government agency, a nonprofit organization or collective, or by one or more vendors. The hosting organization would have to provide many more services than just passively accepting submissions of artifacts and serving downloads from the repository. The organization would need to maintain a substantial service arm. The evaluation of submitted artifacts and the distribution of custom extensions to new artifacts, modifications of existing artifacts to reflect changes in any of the underlying technologies and, most frequently, development of new application-dependent alternatives of existing artifacts would be the prime responsibilities for the hosting organization, 
along with the standard responsibilities for education, training and general maintenance of the system and the artifacts to keep up with the state of the art.

The business process implications of the three alternatives are discussed below.

\subsubsection{Hosting by a government agency}

A government agency could host ADF on the basis of distributing results of governmentsponsored $R \& D$, or a funding mechanism could be set up along the lines of the Agricultural Extension Service operated by the Department of Agriculture or the Manufacturing Extension Partnership administered by NIST (http://www.mep.nist.gov/index.html). The fee structure for artifacts downloaded from ADF as well as for custom modified artifacts, as described above, would depend on the subsidy provided by the funding.

The hosting agency could be expected to have firm policies for accepting, evaluating, and screening submitted candidate artifacts and for updating the system and the artifacts in the repository to reflect developing regulations, healthcare advisories, vocabulary updates, etc., as well as for quality control, validation, verification, and certification of the artifacts released. Whether government hosting entails increasingly bureaucratic procedures and excessive reliance on standards remains to be ascertained, and these effects need to be minimized. The agency would also have to have firm policies for acting on requests for custom modifications; conceivably an advisory panel which would set priorities could guide the agency.

\subsubsection{Hosting by a nonprofit organization or collective}

A nonprofit organization funded by and representing a wide collective of healthcare stakeholders could be set up to host the production version of ADF and the associated services. It is to be expected that the hosting agency could eventually be self-supporting from the fees charged for updates, custom modifications and other services such as education and training. The process for accepting, evaluating, and screening submitted candidate artifacts would be essentially the same as discussed above for a government host. However, the staff needed for custom modifications, and thereby the charges to users, could be substantially reduced by a form of open-source programming: a participating healthcare provider organization could develop the application-dependent alternatives of existing artifacts that it needs and, with suitable quality controls, submit them to the hosting agency for inclusion in the repository for use by others.

Provided that a broad enough range of stakeholders is included in the management of the hosting organization, the issues of accepting, evaluating, updating, quality control, validation, verification, and certification of the artifacts and acting on requests for custom modifications raised above could be expected to be resolved in the normal operation of a participatory collective. 


\subsubsection{Hosting by vendor organization}

It is difficult to conceive of a single commercial for-fee vendor providing all the ADF services outlined above to the entire US healthcare enterprise. As a starter, it is hardly possible to imagine the conditions under which the thousands of participating stakeholder organizations would agree on a single commercial provider for all services. It may be conceivable that a software vendor, on contract to a government healthcare institution, would accept, evaluate, and screen submitted candidate artifacts under the guidance of an advisory council for use by other vendors.

By contrast, it is reasonable to expect that the competitive market of software and service vendors servicing the healthcare industry today would extend the range of its offerings to include commercial versions of ADF and the associated services described earlier, including intake services. It is to be expected that vendors will see ADF services as extensions of their current offerings and will offer these additional services to their current customers as well as attempt to use them to gain additional market share. In a healthy competitive market in ADFrelated services, it is to be expected that issues of pricing, coverage, updating and quality control will be resolved in the marketplace. It is also quite likely that some vendors will attempt to develop niche or boutique markets on the basis of medical specialization, type of healthcare provider organization, etc.

Furthermore, it is to be expected that vendors will tightly couple ADF-related services with their present offerings into vertically integrated "silo" systems. A positive feature of this business approach is that commercial vendors will be more likely to provide direct interfaces to non-medical systems such as payor management and accounting, as they are doing today, than would the other types of hosting discussed (government or collaborative). On the other hand, if experience in other domains is a guide, standardization on a nationwide scale may suffer. The individual vendors' tightly integrated "silos" can achieve tighter interoperability within their respective systems through proprietary procedures than through consensus standards. Issues of interoperability will arise only when data need to be exchanged among different vendors' systems. Groups that may be severely affected by this mismatch are small healthcare entities, such as independent healthcare providers or small local laboratories, which may have to exchange data with several healthcare systems using different vendors' IT systems. In the worst case, the healthcare system can get distorted by alliances formed on the basis of common IT systems rather than health care policies or business interests. These issues may be so severe that an external agency, either governmental or formed by the stakeholders, may be needed to mitigate.

\subsection{Metis prototype architecture}

The initial version of the ADF prototype has been implemented in Metis (14). Metis is a family of client and server products for creating, visualizing, changing, sharing and managing visual enterprise models. Metis provides an information management platform and a meta-model driven repository, combined with visual modeling capabilities. 
Metis Enterprise consists of:

- Metis Desktop - includes the Metis Client Tools for users to view, develop and manage models. These tools are the Model Browser, Model Annotator, Model Editor, Model Designer and Metamodel Developer.

- Metis Enterprise Repository - a scalable and extensible object-based configuration management database (CMDB) that stores and organizes all the data.

- Metis Enterprise Architecture Framework - a reference model based on best practices in enterprises and U.S. federal agencies.

The anticipated architecture of the prototype is shown in Figure 6.

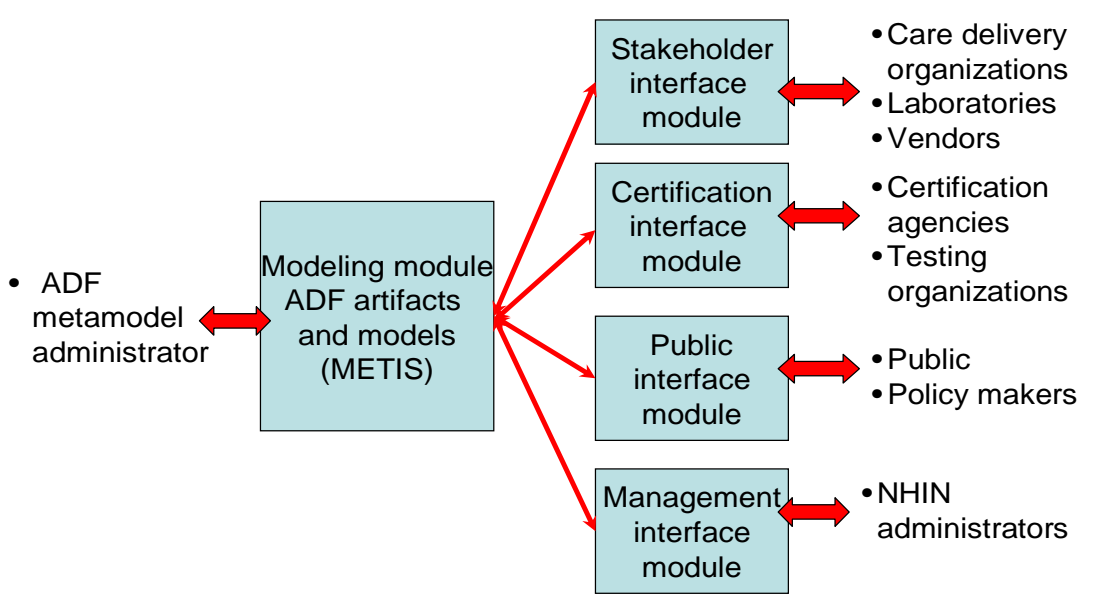

Figure 6. Initial architecture of ADF prototype

ADF will consist of a number of distinct modules. The key module is the modeling module where the ADF metamodels, models, and artifacts are defined and housed. The modeling module is accessible only to the ADF metamodel administrator. The remaining modules are all interface modules for specific constituencies:

- NHIN administrators;

- Care delivery organizations;

- Laboratories;

- Information service providers (vendors);

- Certification and testing agencies (HITSP, Certification Commission for Health Information Technology (CCHIT), etc.);

- Policy makers;

- Public participants.

The interface modules will all be implemented as Web clients of a server that is linked to the modeling module. 


\section{Future work}

In this section, we briefly describe the work we expect to undertake in the second year of the ADF project.

\subsection{Detailed specifications for healthcare network interchange points}

As ONC defines the constraints affecting a health information service provider the ADF team will provide assistance as needed in the development of the specifications and constraints and will work on ensuring that the representations that emerge can be fully supported by the ADF.

\subsection{High level model for future NHIN use cases}

ONC has initiated an effort to define and organize a global metamodel of use cases so as to provide a framework for prioritizing AHIC priorities. The ADF team will work on harmonizing the metamodels with the dual objective of:

- Providing a continuous model of present and future use cases from the high-level ONC model to the low-level model linked to artifacts in ADF; and

- Ensuring that the combined model can be fully supported by the ADF.

\subsection{Detailed use cases for ADF interactions}

The ADF team will develop detailed use cases describing user interactions in at least the following categories:

- Ambulatory EHR;

- Ambulatory EHR with specialties;

- In-patient EHR with amalgamation of services; and

- Health information service providers.

More generally, an attempt will be made to develop a use case for at least one user category for each of the ADF interfaces shown on Figure 6.

\subsection{Mockups of future interactions with ADF and design of interface modules}

In parallel with the use cases described above, mockups of the various interfaces and user interactions will be developed. These will serve as the basis for the design of the interface 
modules as well as of the server that will be interposed between the METIS model and the interfaces.

\subsection{Refinement of ADF architecture}

The activities described above will form the basis for a refinement of the current architecture of ADF into a revised repository which will serve as Version 1.0 of the eventual operational prototype.

\section{Disclaimer}

No approval or endorsement of any commercial product, service or company by the National Institute of Standards and Technology is intended or implied.

\section{References}

(1) ONC Goals, Objectives, and Strategies:

http://www.hhs.gov/healthit/ahic/materials/meeting06/ehr/ONC_goals.doc

(2) Vendor presentations at the NHIN Forum:

http://www.hhs.gov/healthit/documents/AccenturePresentation.pdf

http://www.hhs.gov/healthit/documents/CSCForumslides.pdf

http://www.hhs.gov/healthit/documents/IBM_NHIN_Forum.pdf

http://www.hhs.gov/healthit/documents/NGC_NHIN_Forum.pdf

(3) Functional Requirement Aggregation spreadsheet:

http://www.hhs.gov/healthit/documents/FunctReqAggregation.xls

(4) EHR harmonized use cases dated March 19, 2006:

http://publicaa.ansi.org/sites/apdl/Documents/Standards\%20Activities/Healthcare\%20Informati cs\%20Technology\%20Standards\%20Panel/Technical\%20Committees/AHIC\%20Harmonized

\%20Use\%20Cases/Harmonized\%20EHR\%20-

\%20Lab\%20Use\%20Case\%20Version\%201.0.pdf

(5) BIO-Surveillance harmonized use cases dated March 19, 2006:

http://publicaa.ansi.org/sites/apdl/Documents/Standards\%20Activities/Healthcare\%20Informati cs\%20Technology\%20Standards\%20Panel/Technical\%20Committees/AHIC\%20Harmonized \%20Use\%20Cases/Harmonized\%20Biosurveillance\%20-

\%20Visit\%20Utilization\%20Lab\%20Use\%20Case\%20Version\%201.0.pdf

(6) Consumer Empowerment harmonized use cases dated March 19, 2006:

http://publicaa.ansi.org/sites/apdl/Documents/Standards\%20Activities/Healthcare\%20Informati 
cs\%20Technology\%20Standards\%20Panel/Technical\%20Committees/AHIC\%20Harmonized \%20Use\%20Cases/Harmonized\%20Consumer\%20Empowerment\%20-

\%20Registration\%20and\%20Medication\%20Use\%20Case\%20Version\%201.0.pdf

(7) EHR selected standards dated June 29, 2006:

http://publicaa.ansi.org/sites/apdl/Documents/Standards\%20Activities/Healthcare\%20Informati cs\%20Technology\%20Standards\%20Panel/Standards\%20Selection\%20Final\%20Deliverable, \%20June\%2029/HITSP\%20June\%2029,\%202006\%20Deliverable/Electronic\%20Health\%20R ecords/HITSP_EHR\%20Selected\%20Standards\%20June\%202006\%20-\%20Version\%202.doc

(8) BIO-Surveillance selected standards dated June 29, 2006:

http://publicaa.ansi.org/sites/apdl/Documents/Standards\%20Activities/Healthcare\%20Informati cs\%20Technology\%20Standards\%20Panel/Standards\%20Selection\%20Final\%20Deliverable, \%20June\%2029/HITSP\%20June\%2029,\%202006\%20Deliverable/Biosurveillance/HITSP_BI O\%20Selected\%20Standards\%20June\%202006\%20-\%20Version\%202.doc

(9) Consumer Empowerment selected standards dated June 29, 2006:

http://publicaa.ansi.org/sites/apdl/Documents/Standards\%20Activities/Healthcare\%20Informati cs\%20Technology\%20Standards\%20Panel/Standards\%20Selection\%20Final\%20Deliverable, \%20June\%2029/HITSP\%20June\%2029,\%202006\%20Deliverable/Consumer\%20Empowerme nt/HITSP_CE\%20Selected\%20Standards\%20June\%202006\%20-\%20Version\%202.doc

(10) EHR interoperability specifications dated August 18, 2006:

http://publicaa.ansi.org/sites/apdl/Documents/Standards\%20Activities/Healthcare\%20Informati cs\%20Technology\%20Standards\%20Panel/Interoperability\%20Specification/Electronic\%20He alth\%20Record/EHR\%20IS\%20Documents.zip

(11) BIO-Surveillance interoperability specifications dated August 18, 2006:

http://publicaa.ansi.org/sites/apdl/Documents/Standards\%20Activities/Healthcare\%20Informati cs\%20Technology\%20Standards\%20Panel/Interoperability\%20Specification/Biosurveillance/B IO\%20IS\%20Documents.zip

(12) Consumer Empowerment interoperability specifications dated August 18, 2006: http://publicaa.ansi.org/sites/apdl/Documents/Standards\%20Activities/Healthcare\%20Informati cs\%20Technology\%20Standards\%20Panel/Interoperability\%20Specification/Consumer\%20E mpowerment/CE\%20IS\%20Documents.zip

(13) National Committee on Vital and Health Statistics: http://www.ncvhs.hhs.gov

(14) Metis EA Tool: http://www.troux.com/products/metis 


\section{Appendix A - Data structure}

The table below shows the data structure of artifacts current as of 12/31/2006. Lines preceded by a dot denote attributes.

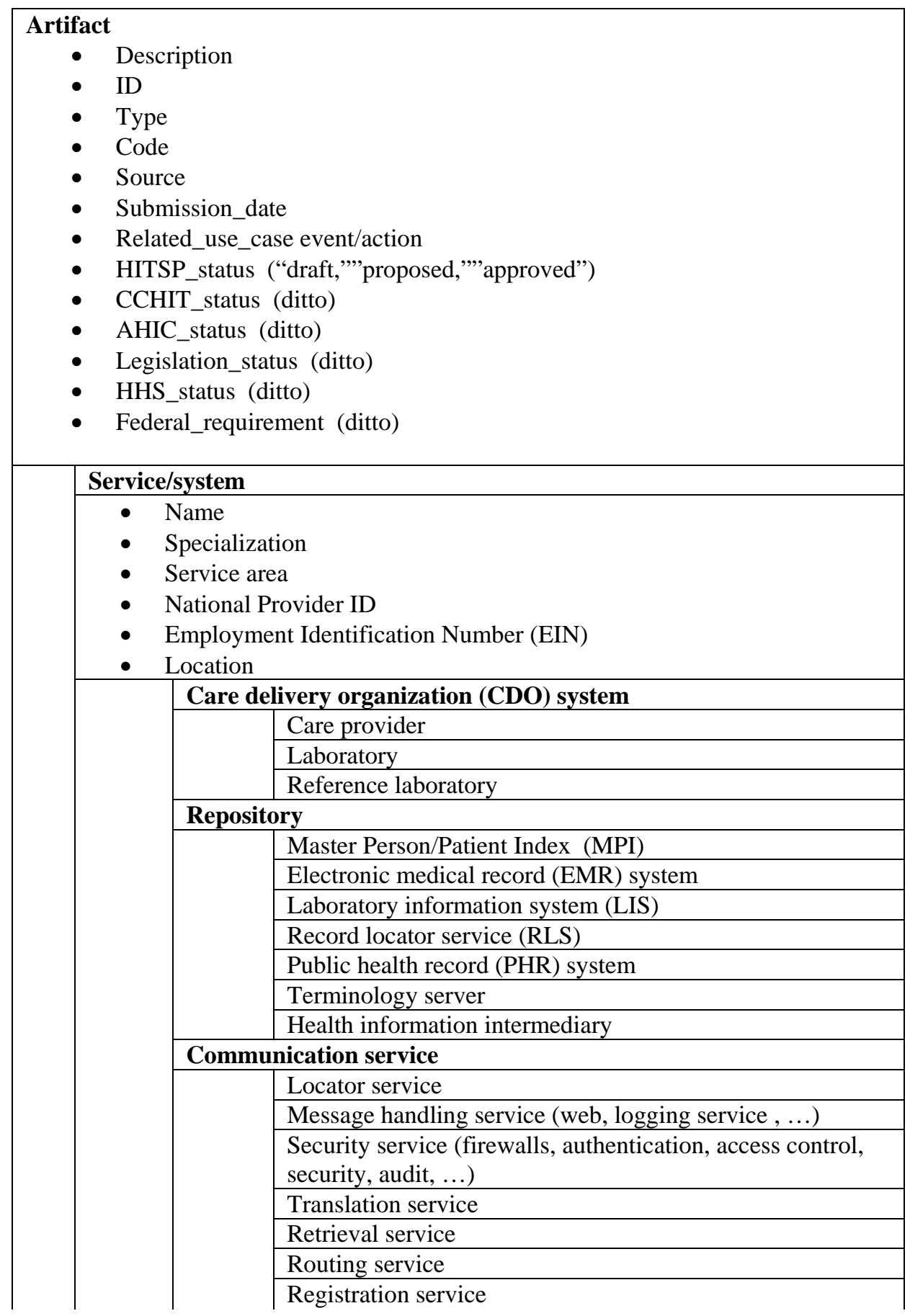




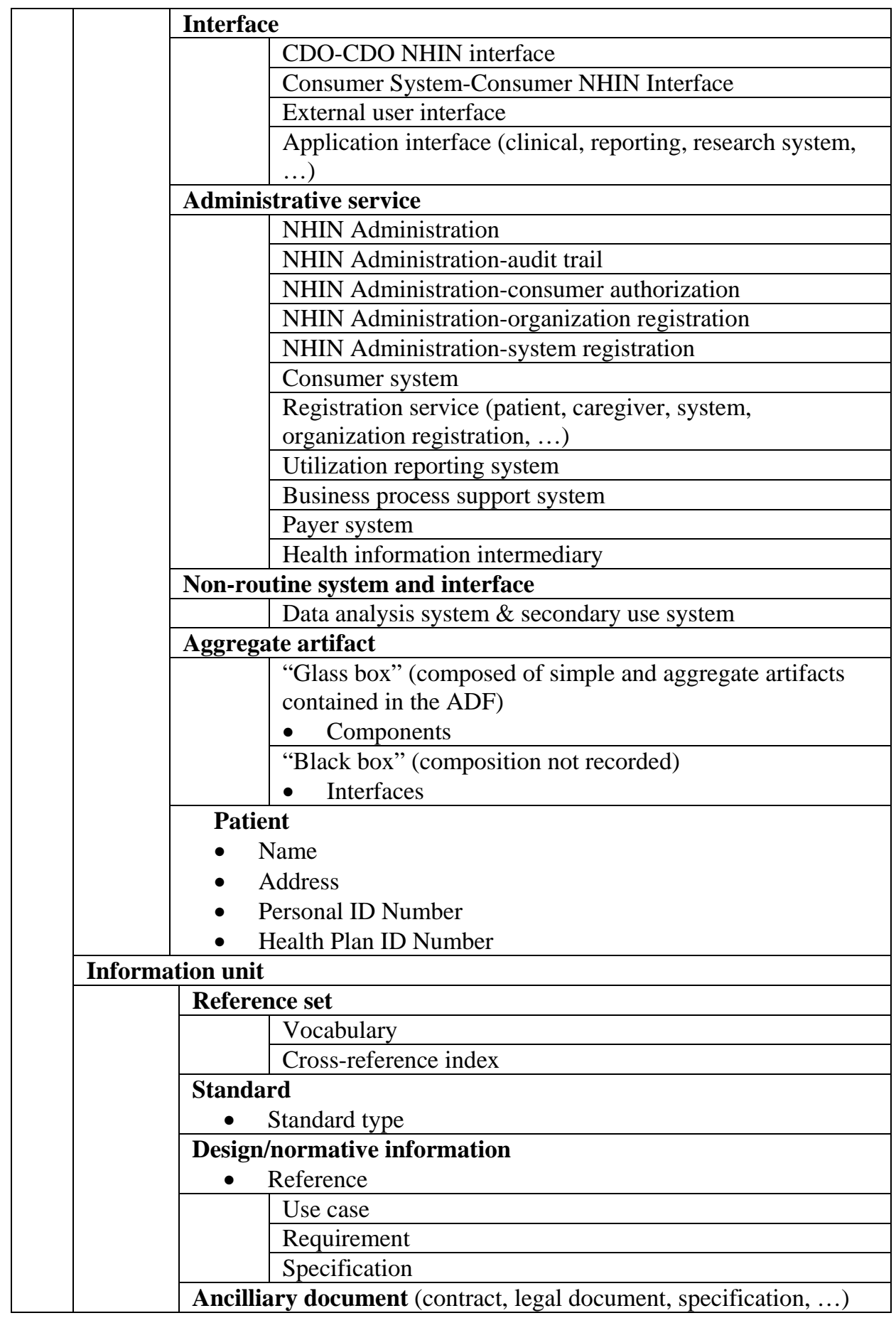




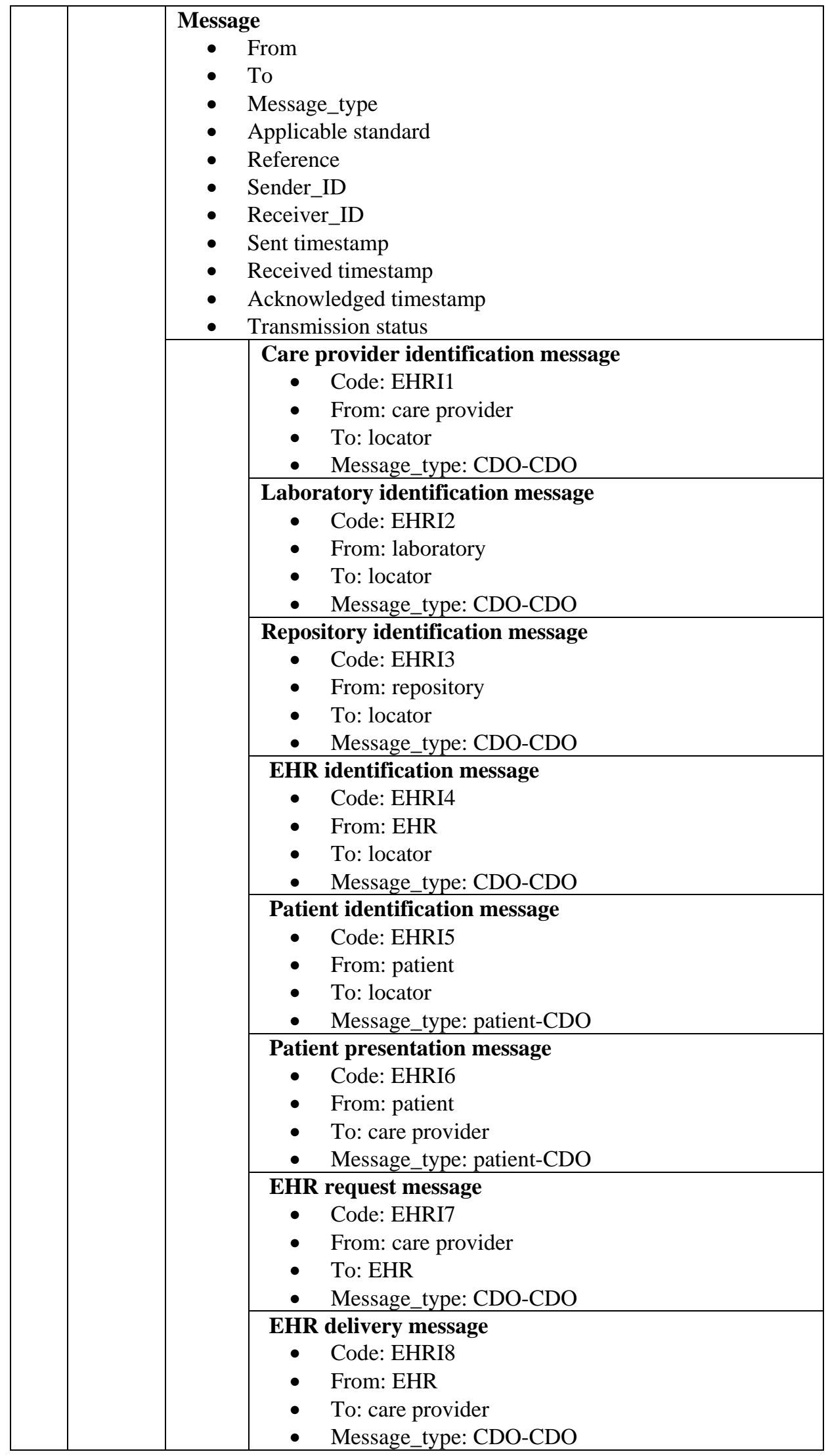




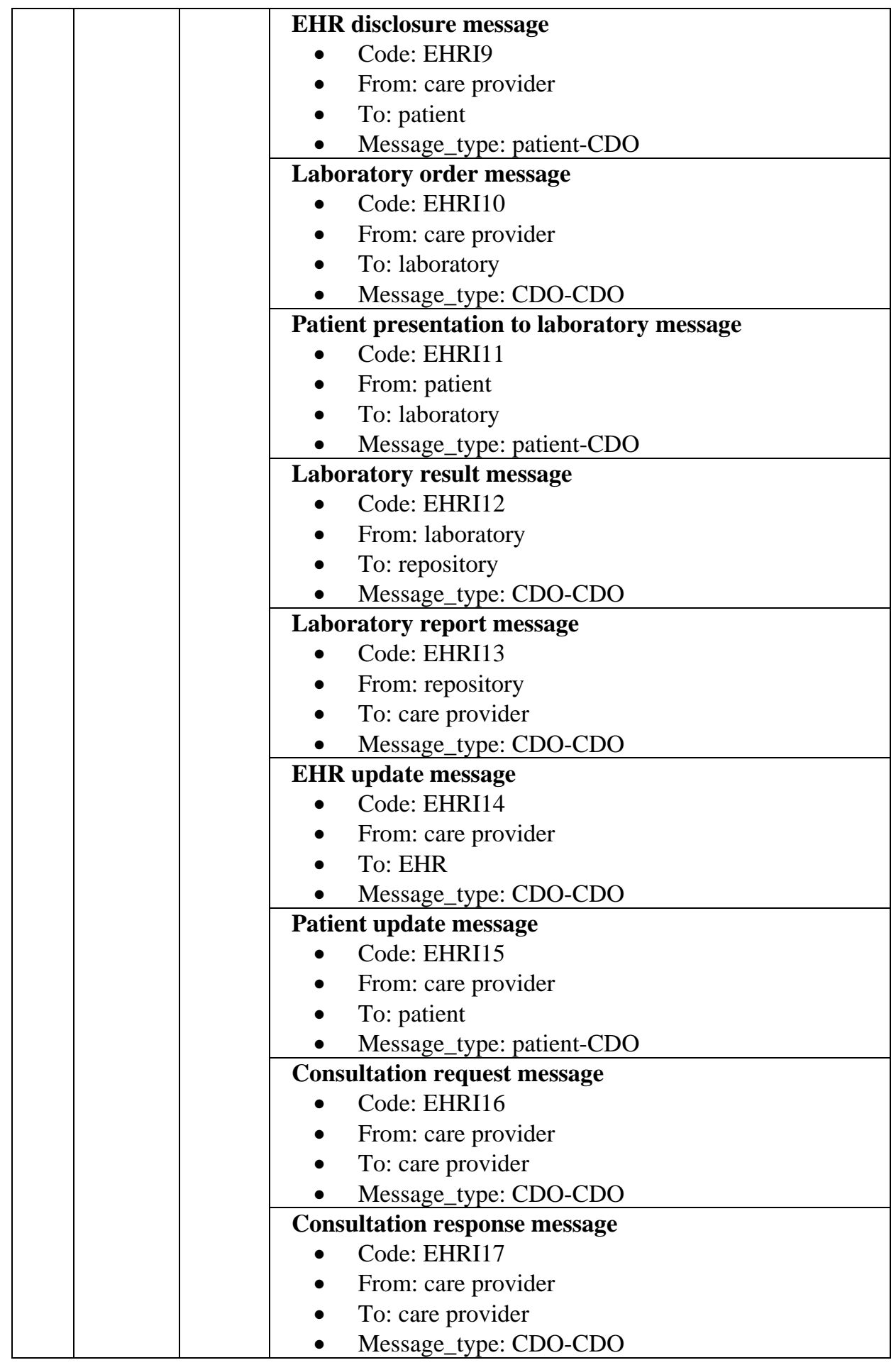

Table A1. Data structure of artifacts 


\section{Appendix B - Correspondence to Use Cases}

The spreadsheets that follows show the correspondence between the use case events/actions in the sequence of HITSP reports and the message artifacts used in this report.

The tan-colored and white rows are taken from three sets of HITSP reports:

1. the harmonized use cases dated March 19, 2006 (4, (5, (6)

2. the selected standards dated June $29,2006(7,(8,(9)$

3. the interoperability specifications dated August 18, 2006 (10, (11, (12).

Where reports 2 and 3 omit certain events or actions from the initial use cases, the cells are left blank. The last set of columns show the ADF message artifact codes and designations. The last column also contains comments in italics on why certain actions were not treated as distinct artifacts. It is to be emphasized that in ADF the actions of sending, receiving, and acknowledging a message, returning an error message to the sender, and acting on that error message are all parts of the message artifact and are therefore not treated separately. The turquoise-colored rows are artifacts (or participant actions on message artifacts) added so that information flows, service precedences, etc., can be modeled and displayed in the ADF. 


\begin{tabular}{|c|c|c|c|c|c|c|c|}
\hline \multicolumn{2}{|c|}{ Harmonized Use Case for Biosurveillance } & \multicolumn{2}{|c|}{$\begin{array}{l}\text { Healthcare Information Technology Standards Panel } \\
\text { Technical Committees Selected Standards June } 29 \text {, } \\
2006 \text { Version } 2.0\end{array}$} & \multicolumn{2}{|c|}{$\begin{array}{l}\text { HITSP Interoperability Specification: Harmonized } \\
\text { Biosurveillance - Visit Utilisation Lab Use Case Version }\end{array}$} & \multicolumn{2}{|r|}{ Draft definition of ADF artifacts } \\
\hline Code & Description & Code & Description & Code & Description & Code & Description \\
\hline 1.1.1.0 & $\begin{array}{l}\text { Event: Filter existing data to } \\
\text { identify data required by public } \\
\text { health agencies }\end{array}$ & 1.1 .1 .0 & $\begin{array}{l}\text { Event: Filter existing data to identify data } \\
\text { required by public health agencies }\end{array}$ & 1.1 .1 .0 & $\begin{array}{l}\text { Event: Filter existing data to identify data required } \\
\text { by public health agencies }\end{array}$ & & \\
\hline 1.1.1.1 & $\begin{array}{l}\text { Action: Filter collected data records } \\
\text { to identify biosurveillance data }\end{array}$ & $\begin{array}{l}1.1 .1 .1 \\
1.1 .1 .1 .1 \\
1.1 .1 .1 .2 \\
1.1 .1 .1 .3\end{array}$ & $\begin{array}{l}\text { Action: Filter collected data records to identify } \\
\text { biosurveillance data } \\
\text { Action: Filter collected data records to identify } \\
\text { biosurveillance data (Lab Results, Visit) } \\
\begin{array}{l}\text { Action: Filter collected data records to identify } \\
\text { biosurveillance data (Resource Utilization) }\end{array}\end{array}$ & 1.1.1.1 & $\begin{array}{l}\text { Action: Filter collected data records to identify } \\
\text { biosurveillance data }\end{array}$ & BIOl1 & Filtered data \\
\hline 1.1.1.2 & Action: Aggregate identified data & & & 1.1.1.2 & Action: Aggregate identified data & BIOI2 & Aggregate data \\
\hline 1.1 .2 .0 & $\begin{array}{l}\text { Event: Anonymize data required by } \\
\text { public health agencies }\end{array}$ & 1.1 .2 .0 & $\begin{array}{l}\text { Event: Anonymize data required by public } \\
\text { health agencies }\end{array}$ & 1.1 .2 .0 & $\begin{array}{l}\text { Event: Anonymize data required by public health } \\
\text { agencies }\end{array}$ & & \\
\hline 1.1.2.1 & $\begin{array}{l}\text { Action: Required data are checked } \\
\text { to ensure full privacy requirement } \\
\text { compliance }\end{array}$ & 1.1.2.1 & $\begin{array}{l}\text { Action: Required data are checked to ensure } \\
\text { full privacy requirement compliance }\end{array}$ & 1.1.2.1 & $\begin{array}{l}\text { Action: Required data are checked to ensure full } \\
\text { privacy requirement compliance }\end{array}$ & & \\
\hline 1.1 .2 .2 & $\begin{array}{l}\text { Action: A randomized data linker is } \\
\text { provided to allow authorized } \\
\text { entities to re-link to patient data }\end{array}$ & 1.1.2.2 & $\begin{array}{l}\text { Action: A randomized data linker is provided to } \\
\text { allow authorized entities to re-link to patient } \\
\text { data }\end{array}$ & 1.1 .2 .2 & $\begin{array}{l}\text { Action: A randomized data linker is provided to } \\
\text { allow authorized entities to re-link to patient data }\end{array}$ & BIOІ3 & Randomized data \\
\hline 1.1.3.0 & $\begin{array}{l}\text { Event: Format data required by } \\
\text { public health agencies }\end{array}$ & 1.1.3.0 & $\begin{array}{l}\text { Event: Format data required by public health } \\
\text { agencies }\end{array}$ & 1.1 .3 .0 & $\begin{array}{l}\text { Event: Format data required by public health } \\
\text { agencies }\end{array}$ & & \\
\hline 1.1.3.1 & $\begin{array}{l}\text { Action: Transform data using } \\
\text { approved standards }\end{array}$ & 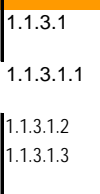 & $\begin{array}{l}\text { Action: Transform data using approved } \\
\text { standards } \\
\text { Action: Transform data using approved } \\
\text { standards (Lab Results) } \\
\text { Action: Transform data using approved standards (Visit) } \\
\text { Action: Transform data using approved standards } \\
\text { (Utilization) }\end{array}$ & |1.1.3.1 & Action: Transform data using approved standards & $\mathrm{BIOl} 4$ & Transformed data \\
\hline 1.1.4.0 & $\begin{array}{l}\text { Event: Identify Public Health } \\
\text { Agencies that must be notified }\end{array}$ & & & 1.1.4.0 & $\begin{array}{l}\text { Event: Identify Public Health Agencies that must be } \\
\text { notified }\end{array}$ & & \\
\hline 1.1.4.1 & $\begin{array}{l}\text { Action: Determine which Public } \\
\text { Health Agencies require } \\
\text { notification }\end{array}$ & & & |1.1.4.1 & $\begin{array}{l}\text { Action: Determine which Public Health Agencies } \\
\text { require notification }\end{array}$ & $\mathrm{BIOl5}$ & PHA request \\
\hline 1.1.5.0 & $\begin{array}{l}\text { Event: Transmit relevant data to } \\
\text { public health agencies }\end{array}$ & 1.1 .5 .0 & $\begin{array}{l}\text { Event: Transmit relevant data to public health } \\
\text { agencies }\end{array}$ & 1.1.5.0 & $\begin{array}{l}\text { Event: Transmit relevant data to public health } \\
\text { agencies }\end{array}$ & & \\
\hline 1.1.5.1 & $\begin{array}{l}\text { Action: Send results to public } \\
\text { health agencies }\end{array}$ & $\begin{array}{l}1.1 .5 .1 \\
1.1 .5 \cdot 1.1 \\
1.1 .5 .1 .2 \\
1.1 .5 .1 .3\end{array}$ & $\begin{array}{l}\text { Action: Send results to public health agencies } \\
\text { Action: Send results to public health agencies } \\
\text { (Lab Results) } \\
\text { Action: Send results to public health agencies } \\
\text { (Visit) } \\
\text { Action: Send results to public health agencies } \\
\text { (Utilization) }\end{array}$ & 1.1.5.1 & Action: Send results to public health agencies & $\mathrm{BIOI6}$ & Biohazard report \\
\hline 1.1.5.2 & $\begin{array}{l}\text { Action: Log interaction between } \\
\text { organization systems and public } \\
\text { health agencies }\end{array}$ & & & 1.1 .5 .2 & $\begin{array}{l}\text { Action: Log interaction between organization } \\
\text { systems and public health agencies }\end{array}$ & & \\
\hline
\end{tabular}




\begin{tabular}{|c|c|c|c|c|c|c|c|}
\hline \multicolumn{2}{|c|}{ Harmonized Use Case for Biosurveillance } & \multicolumn{2}{|c|}{$\begin{array}{l}\text { Healthcare Information Technology Standards Panel } \\
\text { Technical Committees Selected Standards June } 29 \text {, } \\
2006 \text { Version } 2.0\end{array}$} & \multicolumn{2}{|c|}{$\begin{array}{l}\text { HITSP Interoperability Specification: Harmonized } \\
\text { Biosurveillance - Visit Utilisation Lab Use Case Version }\end{array}$} & \multicolumn{2}{|r|}{ Draft definition of ADF artifacts } \\
\hline Code & Description & Code & Description & Code & Description & Code & Description \\
\hline 1.2 .1 .1 & $\begin{array}{l}\text { Action: Filter stored data to identify } \\
\text { biosurveillance data }\end{array}$ & 1.2 .1 .1 & $\begin{array}{l}\text { Action: Filter stored data to identify } \\
\text { biosurveillance data }\end{array}$ & 1.2.1.1 & $\begin{array}{l}\text { Action: Filter stored data to identify biosurveillance } \\
\text { data }\end{array}$ & & \\
\hline 1.2.1.2 & Action: Aggregate identified data & 1.2.1.2 & Action: Aggregate identified data & 1.2.1.2 & Action: Aggregate identified data & & \\
\hline 1.2.2.0 & $\begin{array}{l}\text { Event: Anonymize data required by } \\
\text { public health agencies }\end{array}$ & 1.2.2.0 & $\begin{array}{l}\text { Event: Anonymize data required by public } \\
\text { health agencies }\end{array}$ & $1.2 \cdot 2.0$ & $\begin{array}{l}\text { Event: Anonymize data required by public health } \\
\text { agencies }\end{array}$ & & \\
\hline 1.2.2.1 & $\begin{array}{l}\text { Action: Required data are checked } \\
\text { to ensure full privacy requirement } \\
\text { compliance }\end{array}$ & 1.2.2.1 & $\begin{array}{l}\text { Action: Required data are checked to ensure } \\
\text { full privacy requirement compliance }\end{array}$ & 1.2.2.1 & $\begin{array}{l}\text { Action: Required data are checked to ensure full } \\
\text { privacy requirement compliance }\end{array}$ & & \\
\hline 1.2.2.2 & $\begin{array}{l}\text { Action: A randomized data linker is } \\
\text { provided to allow authorized } \\
\text { entities to re-link to patient data }\end{array}$ & 1.2.2.2 & $\begin{array}{l}\text { Action: A randomized data linker is provided to } \\
\text { allow authorized entities to re-link to patient } \\
\text { data }\end{array}$ & 1.2.2.2 & $\begin{array}{l}\text { Action: A randomized data linker is provided to } \\
\text { allow authorized entities to re-link to patient data }\end{array}$ & & \\
\hline 1.2 .3 .0 & $\begin{array}{l}\text { Event: Format data required by } \\
\text { public health agencies }\end{array}$ & 1.2.3.0 & $\begin{array}{l}\text { Event: Format data required by public health } \\
\text { agencies }\end{array}$ & 1.2.3.0 & $\begin{array}{l}\text { Event: Format data required by public health } \\
\text { agencies }\end{array}$ & & \\
\hline 1.2.3.1 & $\begin{array}{l}\text { Action: Transform data using } \\
\text { approved standards }\end{array}$ & 1.2.3.1 & $\begin{array}{l}\text { Action: Transform data using approved } \\
\text { standards }\end{array}$ & 1.2.3.1 & Action: Transform data using approved standards & & \\
\hline 1.2.4.0 & $\begin{array}{l}\text { Event: Identify Public Health } \\
\text { Agencies that must be notified }\end{array}$ & 1.2.4.0 & $\begin{array}{l}\text { Event: Identify Public Health Agencies that } \\
\text { must be notified }\end{array}$ & 1.2.4.0 & $\begin{array}{l}\text { Event: Identify Public Health Agencies that must be } \\
\text { notified }\end{array}$ & & \\
\hline 1.2.4.1 & $\begin{array}{l}\text { Action: Determine which Public } \\
\text { Health Agencies require } \\
\text { notification }\end{array}$ & 1.2.4.1 & $\begin{array}{l}\text { Action: Determine which Public Health } \\
\text { Agencies require notification }\end{array}$ & 1.2.4.1 & $\begin{array}{l}\text { Action: Determine which Public Health Agencies } \\
\text { require notification }\end{array}$ & & \\
\hline 1.2 .5 .0 & $\begin{array}{l}\text { Event: Transmit relevant data to } \\
\text { public health agencies }\end{array}$ & 1.2 .5 .0 & $\begin{array}{l}\text { Event: Transmit relevant data to public health } \\
\text { agencies }\end{array}$ & 1.2 .5 .0 & $\begin{array}{l}\text { Event: Transmit relevant data to public health } \\
\text { agencies }\end{array}$ & & \\
\hline 1.2.5.1 & $\begin{array}{l}\text { Action: Send results to public } \\
\text { health agencies }\end{array}$ & 1.2.5.1 & Action: Send results to public health agencies & 1.2.5.1 & Action: Send results to public health agencies & & \\
\hline 1.2.5.2 & $\begin{array}{l}\text { Action: Log interaction between } \\
\text { organization systems and public } \\
\text { health agencies }\end{array}$ & 1.2.5.2 & $\begin{array}{l}\text { Action: Log interaction between organization } \\
\text { systems and public health agencies }\end{array}$ & 1.2.5.2 & $\begin{array}{l}\text { Action: Log interaction between organization } \\
\text { systems and public health agencies }\end{array}$ & & \\
\hline 1.3.1.0 & $\begin{array}{l}\text { Event: Provide listing of required } \\
\text { biosurveillance data }\end{array}$ & 1.3.1.0 & $\begin{array}{l}\text { Event: Provide listing of required } \\
\text { biosurveillance data }\end{array}$ & 1.3.1.0 & $\begin{array}{l}\text { Event: Provide listing of required biosurveillance } \\
\text { data }\end{array}$ & & \\
\hline 1.3.1.1 & $\begin{array}{l}\text { Action: Notify involved } \\
\text { organizations of data that must be } \\
\text { transmitted to Public Health } \\
\text { Agencies }\end{array}$ & 1.3.1.1 & $\begin{array}{l}\text { Action: Notify involved organizations of data } \\
\text { that must be transmitted to Public Health } \\
\text { Agencies }\end{array}$ & 1.3.1.1 & $\begin{array}{l}\text { Action: Notify involved organizations of data that } \\
\text { must be transmitted to Public Health Agencies }\end{array}$ & $\mathrm{BlOl7}$ & Notification to CDOs \\
\hline 1.3 .2 .0 & $\begin{array}{l}\text { Event: Receive biosurveillance } \\
\text { data }\end{array}$ & 1.3.2.0 & Event: Receive biosurveillance data & 1.3.2.0 & Event: Receive biosurveillance data & & \\
\hline 1.3.2.1 & $\begin{array}{l}\text { Action: Receive clinical data from } \\
\text { the all data sources. }\end{array}$ & 1.3.2.1 & $\begin{array}{l}\text { Action: Receive clinical data from the all data } \\
\text { sources. }\end{array}$ & 1.3.2.1 & $\begin{array}{l}\text { Action: Receive clinical data from the all data } \\
\text { sources. }\end{array}$ & & \\
\hline 1.3.2.2 & $\begin{array}{l}\text { Action: Verify authenticity of } \\
\text { transmission contents }\end{array}$ & 1.3.2.2 & $\begin{array}{l}\text { Action: Verify authenticity of transmission } \\
\text { contents }\end{array}$ & 1.3.2.2 & Action: Verify authenticity of transmission contents & & \\
\hline 1.3.2.3 & $\begin{array}{l}\text { Action: Acknowledge receipt of } \\
\text { clinical data }\end{array}$ & 1.3.2.3 & Action: Acknowledge receipt of clinical data & 1.3.2.3 & Action: Acknowledge receipt of clinical data & & \\
\hline 1.3.2.4 & $\begin{array}{l}\text { Action: Log receipt and storage of } \\
\text { lab test results }\end{array}$ & & & 1.3.2.4 & Action: Log receipt and storage of lab test results & & \\
\hline
\end{tabular}




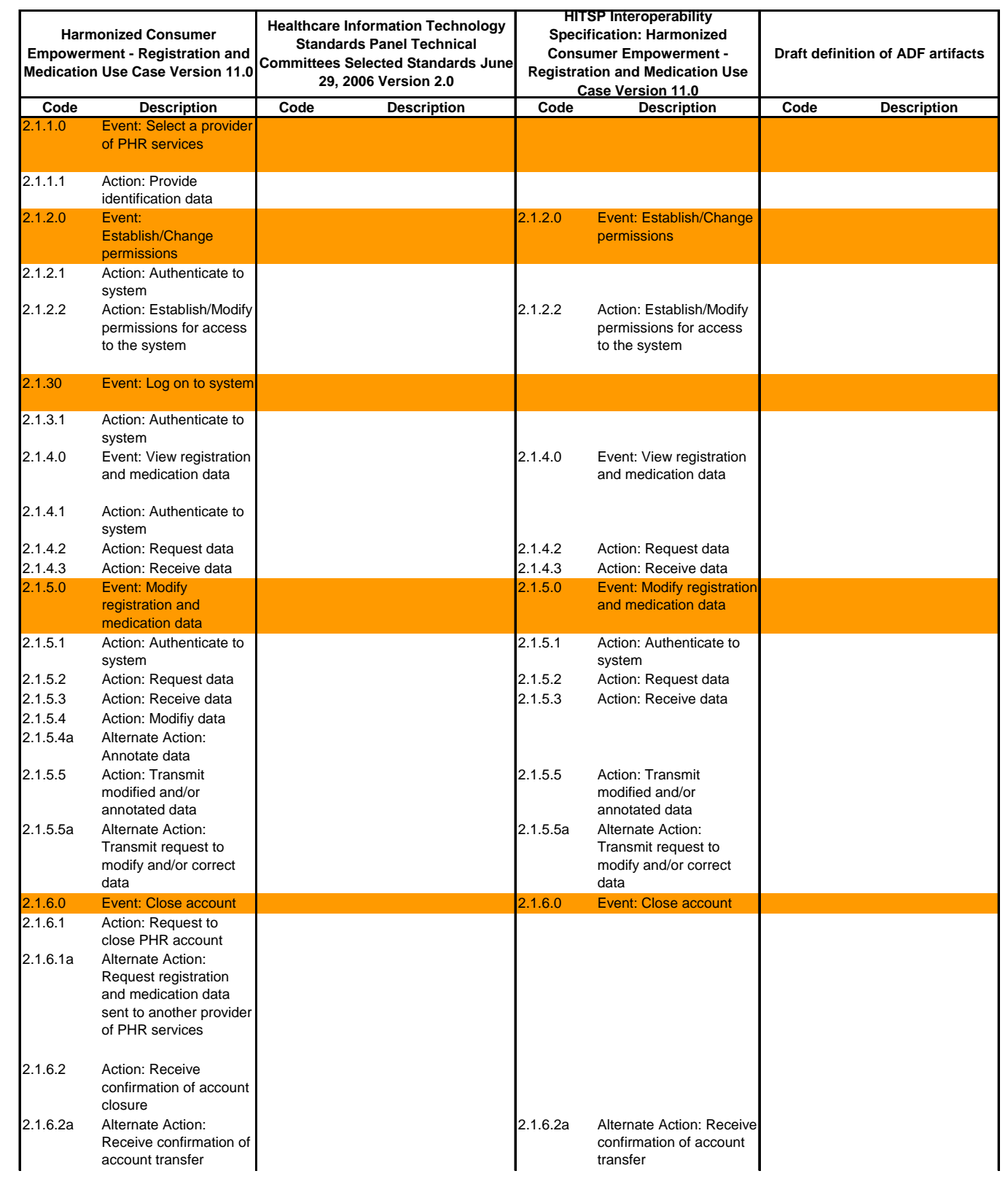




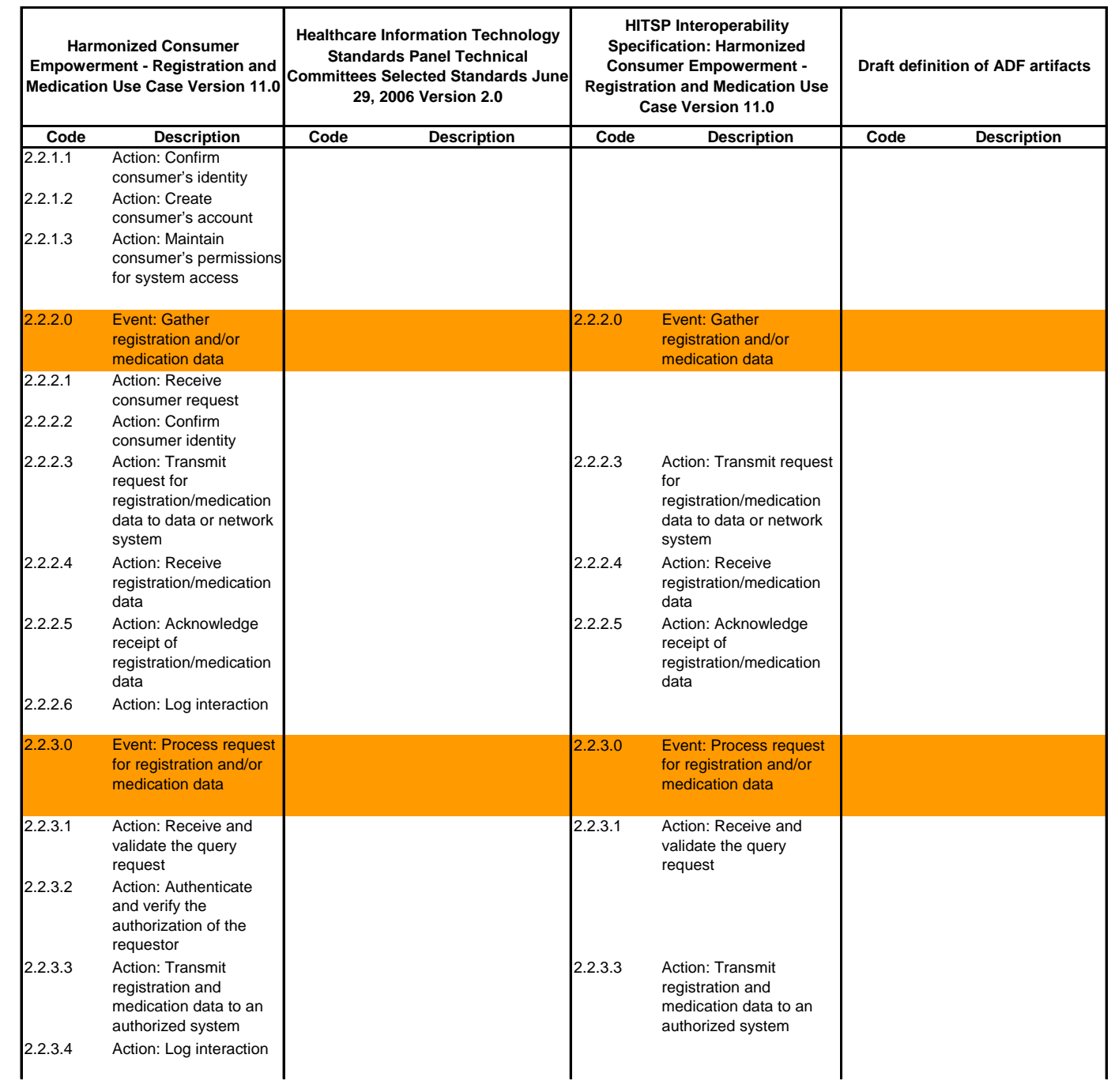




\begin{tabular}{|c|c|c|c|c|c|c|c|}
\hline \multicolumn{2}{|c|}{$\begin{array}{c}\text { Harmonized Consumer } \\
\text { Empowerment - Registration and } \\
\text { Medication Use Case Version } 11.0\end{array}$} & \multicolumn{2}{|c|}{\begin{tabular}{|} 
Healthcare Information Technology \\
Standards Panel Technical \\
Committees Selected Standards June \\
29,2006 Version 2.0
\end{tabular}} & \multicolumn{2}{|c|}{$\begin{array}{c}\text { HITSP Interoperability } \\
\text { Specification: Harmonized } \\
\text { Consumer Empowerment - } \\
\text { Registration and Medication Use } \\
\text { Case Version } 11.0\end{array}$} & \multicolumn{2}{|c|}{ Draft definition of ADF artifacts } \\
\hline Code & Description & Code & Description & Code & Description & Code & Description \\
\hline $\begin{array}{l}2.2 .4 .1 \\
2.2 .4 .2\end{array}$ & $\begin{array}{l}\text { Action: Receive and } \\
\text { validate query } \\
\text { Action: Authenticate } \\
\text { and verify the } \\
\text { authorization of the } \\
\text { requestor }\end{array}$ & & & & & & \\
\hline 2.2.4.3 & Action: Terminate acco & & & & & & \\
\hline 2.2.4.3a & $\begin{array}{l}\text { Alternate Action: } \\
\text { Transmit registration } \\
\text { and medication data to } \\
\text { the new provider of } \\
\text { PHR services }\end{array}$ & & & 2.2.4.3a & $\begin{array}{l}\text { Alternate Action: } \\
\text { Transmit registration and } \\
\text { medication data to the } \\
\text { new provider of PHR } \\
\text { services }\end{array}$ & & \\
\hline 2.2.4.4 & $\begin{array}{l}\text { Action: Transmit } \\
\text { confirmation to } \\
\text { consumer }\end{array}$ & & & & & & \\
\hline 2.2.4.5 & Action: Log interaction & & & & & & \\
\hline 2.3.1.0 & $\begin{array}{l}\text { Event: View registration } \\
\text { and/or medication data }\end{array}$ & & & 2.3.1.0 & $\begin{array}{l}\text { Event: View registration } \\
\text { and/or medication data }\end{array}$ & & \\
\hline 2.3.1.1 & $\begin{array}{l}\text { Action: Submit } \\
\text { authentication } \\
\text { information to PHR }\end{array}$ & & & & & & \\
\hline 2.3.1.2 & $\begin{array}{l}\text { Action: Receive } \\
\text { registration and } \\
\text { medication data }\end{array}$ & & & & & & \\
\hline 2.3.2.0 & $\begin{array}{l}\text { Event: Integrate } \\
\text { registration data into } \\
\text { EHR or other care } \\
\text { system }\end{array}$ & & & 2.3 .2 .0 & $\begin{array}{l}\text { Event: Integrate } \\
\text { registration data into } \\
\text { EHR or other care } \\
\text { system }\end{array}$ & & \\
\hline \multirow[t]{2}{*}{ 2.3.2.1 } & $\begin{array}{l}\text { Action: Transmit } \\
\text { request for } \\
\text { registration/medication } \\
\text { data to provider of PHR } \\
\text { services }\end{array}$ & & & 2.3.2.1 & $\begin{array}{l}\text { Action: Transmit request } \\
\text { for } \\
\text { registration/medication } \\
\text { data to provider of PHR } \\
\text { services }\end{array}$ & & \\
\hline & & & & 2.3.2.1a & $\begin{array}{l}\text { Receive medication data } \\
\text { (probably unitentionally } \\
\text { left out of Use Case } \\
\text { Event List) }\end{array}$ & & \\
\hline 2.3.2.2 & $\begin{array}{l}\text { Action: Accept data into } \\
\text { EHR system }\end{array}$ & & & 2.3 .2 .2 & $\begin{array}{l}\text { Action: Accept data into } \\
\text { EHR system }\end{array}$ & & \\
\hline 2.3.2.3 & $\begin{array}{l}\text { Action: Confirm data } \\
\text { integrity }\end{array}$ & & & 2.3 .2 .3 & $\begin{array}{l}\text { Action: Confirm data } \\
\text { integrity }\end{array}$ & & \\
\hline 2.3.2.3a & $\begin{array}{l}\text { Alternate Action: } \\
\text { Produce exception list } \\
\text { of errors }\end{array}$ & & & 2.3.2.3a & $\begin{array}{l}\text { Alternate Action: } \\
\text { Produce exception list of } \\
\text { errors }\end{array}$ & & \\
\hline 2.3.2.4 & $\begin{array}{l}\text { Action: Parse and } \\
\text { validate results content }\end{array}$ & & & 2.3.2.4 & $\begin{array}{l}\text { Action: Parse and } \\
\text { validate results content }\end{array}$ & & \\
\hline 2.3.2.5 & $\begin{array}{l}\text { Action: Acknowledge } \\
\text { receipt of registration } \\
\text { and medication data }\end{array}$ & & & 2.3.2.5 & $\begin{array}{l}\text { Action: Acknowledge } \\
\text { receipt of registration } \\
\text { and medication data }\end{array}$ & & \\
\hline 2.3.2.6 & Action: Log interaction & & & 2.3.2.6 & Action: Log interaction & & \\
\hline
\end{tabular}




\begin{tabular}{|c|c|c|c|c|c|c|c|}
\hline \multicolumn{2}{|c|}{$\begin{array}{c}\text { Harmonized Consumer } \\
\text { Empowerment - Registration and } \\
\text { Medication Use Case Version } 11.0\end{array}$} & \multicolumn{2}{|c|}{$\begin{array}{l}\text { Healthcare Information Technology } \\
\text { Standards Panel Technical } \\
\text { Committees Selected Standards June } \\
29,2006 \text { Version } 2.0\end{array}$} & \multicolumn{2}{|c|}{$\begin{array}{c}\text { HITSP Interoperability } \\
\text { Specification: Harmonized } \\
\text { Consumer Empowerment - } \\
\text { Registration and Medication Use } \\
\text { Case Version 11.0 }\end{array}$} & \multicolumn{2}{|c|}{ Draft definition of ADF artifacts } \\
\hline Code & Description & Code & Description & Code & Description & Code & Description \\
\hline 2.3 .3 .1 & $\begin{array}{l}\text { Action: Receive and } \\
\text { validate the query } \\
\text { request }\end{array}$ & & & 2.3 .3 .1 & $\begin{array}{l}\text { Action: Receive and } \\
\text { validate the query } \\
\text { request }\end{array}$ & & \\
\hline 2.3.3.2 & $\begin{array}{l}\text { Action: Authenticate } \\
\text { and verify the } \\
\text { authorization of the } \\
\text { requestor. }\end{array}$ & & & 2.3.3.2 & $\begin{array}{l}\text { Action: Authenticate and } \\
\text { verify the authorization of } \\
\text { the requestor. }\end{array}$ & & \\
\hline 2.3.3.3 & $\begin{array}{l}\text { Action: Transmit } \\
\text { registration and } \\
\text { medication data to an } \\
\text { authorized system }\end{array}$ & & & 2.3.3.3 & $\begin{array}{l}\text { Action: Transmit } \\
\text { registration and } \\
\text { medication data to an } \\
\text { authorized system }\end{array}$ & & \\
\hline 2.3.3.4 & Action: Log interaction & & & 2.3.3.4 & Action: Log interaction & & \\
\hline 2.4.1.0 & $\begin{array}{l}\text { Event: Process request } \\
\text { for registration and/or } \\
\text { medication data }\end{array}$ & & & 2.4.1.0 & $\begin{array}{l}\text { Event: Process request } \\
\text { for registration and/or } \\
\text { medication data }\end{array}$ & & \\
\hline 2.4.1.1 & $\begin{array}{l}\text { Action: Receive and } \\
\text { validate the query } \\
\text { request }\end{array}$ & & & 2.4.1.1 & $\begin{array}{l}\text { Action: Receive and } \\
\text { validate the query } \\
\text { request }\end{array}$ & & \\
\hline 2.4.1.2 & $\begin{array}{l}\text { Action: Authenticate } \\
\text { and verify the } \\
\text { authorization of the } \\
\text { requestor }\end{array}$ & & & & & & \\
\hline 2.4.1.3 & $\begin{array}{l}\text { Action: Authorize } \\
\text { release of registration } \\
\text { and medication data }\end{array}$ & & & & & & \\
\hline 2.4.1.4 & $\begin{array}{l}\text { Action: Transmit } \\
\text { registration and } \\
\text { medication data to an } \\
\text { authorized system }\end{array}$ & & & 2.4.1.4 & $\begin{array}{l}\text { Action: Transmit } \\
\text { registration and } \\
\text { medication data to an } \\
\text { authorized system }\end{array}$ & & \\
\hline 2.4.1.5 & Action: Log interaction & & & & & & \\
\hline
\end{tabular}




\begin{tabular}{|c|c|c|c|c|c|}
\hline \multicolumn{2}{|c|}{\begin{tabular}{c|} 
Harmonized Consumer \\
Empowerment - Registration and \\
Medication Use Case Version 11.0
\end{tabular}} & \multirow{2}{*}{\begin{tabular}{|c|} 
Healthcare Information Technology \\
Standards Panel Technical \\
Committees Selected Standards June \\
29,2006 Version 2.0 \\
\end{tabular}} & \multicolumn{2}{|c|}{\begin{tabular}{c|} 
HITSP Interoperability \\
Specification: Harmonized \\
Consumer Empowerment - \\
Registration and Medication Use \\
Case Version 11.0
\end{tabular}} & \multirow[t]{2}{*}{ Draft definition of ADF artifacts } \\
\hline 2.2 .4 .0 & Event: Close account & & 2.2 .4 .0 & Event: Close account & \\
\hline $\begin{array}{l}2.2 .4 .1 \\
2.2 .4 .2\end{array}$ & $\begin{array}{l}\text { Action: Receive and } \\
\text { validate query } \\
\text { Action: Authenticate } \\
\text { and verify the } \\
\text { authorization of the } \\
\text { requestor }\end{array}$ & & & & \\
\hline 2.2.4.3 & Action: Terminate acco & & & & \\
\hline 2.2.4.3a & $\begin{array}{l}\text { Alternate Action: } \\
\text { Transmit registration } \\
\text { and medication data to } \\
\text { the new provider of } \\
\text { PHR services }\end{array}$ & & 2.2.4.3a & $\begin{array}{l}\text { Alternate Action: } \\
\text { Transmit registration and } \\
\text { medication data to the } \\
\text { new provider of PHR } \\
\text { services }\end{array}$ & \\
\hline 2.2.4.4 & $\begin{array}{l}\text { Action: Transmit } \\
\text { confirmation to } \\
\text { consumer }\end{array}$ & & & & \\
\hline 2.2.4.5 & Action: Log interaction & & & & \\
\hline 2.3.1.0 & $\begin{array}{l}\text { Event: View registration } \\
\text { and/or medication data }\end{array}$ & & 2.3.1.0 & $\begin{array}{l}\text { Event: View registration } \\
\text { and/or medication data }\end{array}$ & \\
\hline 2.3.1.1 & $\begin{array}{l}\text { Action: Submit } \\
\text { authentication } \\
\text { information to PHR }\end{array}$ & & & & \\
\hline 2.3.1.2 & $\begin{array}{l}\text { Action: Receive } \\
\text { registration and } \\
\text { medication data }\end{array}$ & & & & \\
\hline 2.3.2.0 & $\begin{array}{l}\text { Event: Integrate } \\
\text { registration data into } \\
\text { EHR or other care } \\
\text { system }\end{array}$ & & 2.3 .2 .0 & $\begin{array}{l}\text { Event: Integrate } \\
\text { registration data into } \\
\text { EHR or other care } \\
\text { system }\end{array}$ & \\
\hline \multirow[t]{2}{*}{ 2.3.2.1 } & $\begin{array}{l}\text { Action: Transmit } \\
\text { request for } \\
\text { registration/medication } \\
\text { data to provider of PHR } \\
\text { services }\end{array}$ & & 2.3.2.1 & $\begin{array}{l}\text { Action: Transmit request } \\
\text { for } \\
\text { registration/medication } \\
\text { data to provider of PHR } \\
\text { services }\end{array}$ & \\
\hline & & & 2.3.2.1a & $\begin{array}{l}\text { Receive medication data } \\
\text { (probably unitentionally } \\
\text { left out of Use Case } \\
\text { Event List) }\end{array}$ & \\
\hline 2.3.2.2 & $\begin{array}{l}\text { Action: Accept data into } \\
\text { EHR system }\end{array}$ & & 2.3.2.2 & $\begin{array}{l}\text { Action: Accept data into } \\
\text { EHR system }\end{array}$ & \\
\hline 2.3.2.3 & $\begin{array}{l}\text { Action: Confirm data } \\
\text { integrity }\end{array}$ & & 2.3.2.3 & $\begin{array}{l}\text { Action: Confirm data } \\
\text { integrity }\end{array}$ & \\
\hline 2.3.2.3a & $\begin{array}{l}\text { Alternate Action: } \\
\text { Produce exception list } \\
\text { of errors }\end{array}$ & & 2.3.2.3a & $\begin{array}{l}\text { Alternate Action: } \\
\text { Produce exception list of } \\
\text { errors }\end{array}$ & \\
\hline 2.3.2.4 & $\begin{array}{l}\text { Action: Parse and } \\
\text { validate results content }\end{array}$ & & 2.3 .2 .4 & $\begin{array}{l}\text { Action: Parse and } \\
\text { validate results content }\end{array}$ & \\
\hline 2.3.2.5 & $\begin{array}{l}\text { Action: Acknowledge } \\
\text { receipt of registration } \\
\text { and medication data }\end{array}$ & & 2.3.2.5 & $\begin{array}{l}\text { Action: Acknowledge } \\
\text { receipt of registration } \\
\text { and medication data }\end{array}$ & \\
\hline 2.3.2.6 & Action: Log interaction & & 2.3 .2 .6 & Action: Log interaction & \\
\hline
\end{tabular}




\begin{tabular}{|c|c|c|c|c|c|}
\hline \multicolumn{2}{|c|}{$\begin{array}{l}\text { Harmonized Consumer } \\
\text { Empowerment - Registration and } \\
\text { Medication Use Case Version } 11.0\end{array}$} & \multirow[t]{2}{*}{\begin{tabular}{|c|} 
Healthcare Information Technology \\
Standards Panel Technical \\
Committees Selected Standards June \\
29,2006 Version 2.0
\end{tabular}} & \multicolumn{2}{|c|}{$\begin{array}{c}\text { HITSP Interoperability } \\
\text { Specification: Harmonized } \\
\text { Consumer Empowerment - } \\
\text { Registration and Medication Use } \\
\text { Case Version 11.0 }\end{array}$} & \multirow[t]{2}{*}{ Draft definition of ADF artifacts } \\
\hline 2.3 .3 .0 & $\begin{array}{l}\text { Event: Process } \\
\text { requested data }\end{array}$ & & 2.3 .3 .0 & $\begin{array}{l}\text { Event: Process } \\
\text { requested data }\end{array}$ & \\
\hline 2.3.3.1 & $\begin{array}{l}\text { Action: Receive and } \\
\text { validate the query } \\
\text { request }\end{array}$ & & 2.3.3.1 & $\begin{array}{l}\text { Action: Receive and } \\
\text { validate the query } \\
\text { request }\end{array}$ & \\
\hline 2.3.3.2 & $\begin{array}{l}\text { Action: Authenticate } \\
\text { and verify the } \\
\text { authorization of the } \\
\text { requestor. }\end{array}$ & & 2.3.3.2 & $\begin{array}{l}\text { Action: Authenticate and } \\
\text { verify the authorization of } \\
\text { the requestor. }\end{array}$ & \\
\hline 2.3.3.3 & $\begin{array}{l}\text { Action: Transmit } \\
\text { registration and } \\
\text { medication data to an } \\
\text { authorized system }\end{array}$ & & 2.3.3.3 & $\begin{array}{l}\text { Action: Transmit } \\
\text { registration and } \\
\text { medication data to an } \\
\text { authorized system }\end{array}$ & \\
\hline 2.3.3.4 & Action: Log interaction & & 2.3.3.4 & Action: Log interaction & \\
\hline 2.4.1.0 & $\begin{array}{l}\text { Event: Process request } \\
\text { for registration and/or } \\
\text { medication data }\end{array}$ & & 2.4.1.0 & $\begin{array}{l}\text { Event: Process request } \\
\text { for registration and/or } \\
\text { medication data }\end{array}$ & \\
\hline 2.4.1.1 & $\begin{array}{l}\text { Action: Receive and } \\
\text { validate the query } \\
\text { request }\end{array}$ & & 2.4.1.1 & $\begin{array}{l}\text { Action: Receive and } \\
\text { validate the query } \\
\text { request }\end{array}$ & \\
\hline 2.4.1.2 & $\begin{array}{l}\text { Action: Authenticate } \\
\text { and verify the } \\
\text { authorization of the } \\
\text { requestor }\end{array}$ & & & & \\
\hline 2.4.1.3 & $\begin{array}{l}\text { Action: Authorize } \\
\text { release of registration } \\
\text { and medication data }\end{array}$ & & & & \\
\hline 2.4.1.4 & $\begin{array}{l}\text { Action: Transmit } \\
\text { registration and } \\
\text { medication data to an } \\
\text { authorized system }\end{array}$ & & 2.4.1.4 & $\begin{array}{l}\text { Action: Transmit } \\
\text { registration and } \\
\text { medication data to an } \\
\text { authorized system }\end{array}$ & \\
\hline 2.4.1.5 & Action: Log interaction & & & & \\
\hline
\end{tabular}




\begin{tabular}{|c|c|c|c|c|c|c|c|}
\hline \multicolumn{2}{|c|}{$\begin{array}{c}\text { Harmonized Use Case for Electronic } \\
\text { Health Records (Laboratory Result Reporting) } \\
\text { March 19, } 2006\end{array}$} & \multicolumn{2}{|c|}{$\begin{array}{c}\text { Healthcare Information Technology } \\
\text { Standards Panel Technical Committees } \\
\text { Selected Standards June 29, 2006 Version } \\
2.0\end{array}$} & \multicolumn{2}{|c|}{$\begin{array}{c}\text { HITSP Interoperability Specification: EHR } \\
\text { Laboratory Results Reporting } \\
\text { August 18, 2006 } \\
\text { Version 1.0 }\end{array}$} & \multicolumn{2}{|c|}{ Draft definition of ADF artifacts } \\
\hline Code & Description & Code & Description & Code & Description & Code & Description \\
\hline 3.1 .1 .0 & $\begin{array}{l}\text { Event: Provide patient identity } \\
\text { information, update as needed }\end{array}$ & 3.1 .1 .0 & $\begin{array}{l}\text { Event: Provide patient identity } \\
\text { information, update as needed }\end{array}$ & 3.1 .1 .0 & $\begin{array}{l}\text { Event: Provide patient identity } \\
\text { information, update as needed }\end{array}$ & L15 & patient identification \\
\hline 3.1.1.1 & Action: Provide identification data & 3.1.1.1 & Action : Provide identification data & 3.1.1.1 & $\begin{array}{l}\text { Action : Provide identification } \\
\text { data }\end{array}$ & & \\
\hline 3.1.2.0 & $\begin{array}{l}\text { Event: Identify providers of care, } \\
\text { update as needed }\end{array}$ & 3.1 .2 .0 & $\begin{array}{l}\text { Event: Identify providers of care, } \\
\text { update as needed }\end{array}$ & 3.1 .2 .0 & $\begin{array}{l}\text { Event: Identify providers of care, } \\
\text { update as needed }\end{array}$ & LI6 & $\begin{array}{l}\text { identification of patient's care } \\
\text { provider(s) }\end{array}$ \\
\hline 3.1 .2 .1 & Action: Provide list of providers of care & 3.1.2.1 & $\begin{array}{l}\text { Action: Provide list of providers of } \\
\text { care }\end{array}$ & 3.1.2.1 & $\begin{array}{l}\text { Action: Provide list of providers } \\
\text { of care }\end{array}$ & & \\
\hline \multirow[t]{2}{*}{$3.1 .2 .1 \mathrm{a}$} & $\begin{array}{l}\text { Alternate Action: Indicate that test } \\
\text { result results should not be made } \\
\text { available to other providers of care }\end{array}$ & $3.1 .2 .1 \mathrm{a}$ & $\begin{array}{l}\text { Alternate Action: Indicate that test } \\
\text { result results should not be made } \\
\text { available to other providers of care }\end{array}$ & 3.1.2.1a & $\begin{array}{l}\text { Alternate Action: Indicate that } \\
\text { test result results should not be } \\
\text { made available to other } \\
\text { providers of care }\end{array}$ & & \\
\hline & & & & & & $\begin{array}{l}\text { LI7 } \\
\text { LI12 } \\
\text { LI1 }\end{array}$ & $\begin{array}{l}\text { patient presentation (to } \\
\text { clinician) } \\
\text { patient presentation (to } \\
\text { laboratory) } \\
\text { care provider identification }\end{array}$ \\
\hline 3.2.1.0 & $\begin{array}{l}\text { Event: Integrate results and view in } \\
\text { EHR }\end{array}$ & 3.2.1.0 & $\begin{array}{l}\text { Event: Integrate results and view in } \\
\text { EHR }\end{array}$ & 3.2.1.0 & $\begin{array}{l}\text { Event: Integrate results and view } \\
\text { in EHR }\end{array}$ & & \\
\hline 3.2.1.1 & $\begin{array}{l}\text { Action: Receive lab test result as } \\
\text { ordering clinician or provided of care }\end{array}$ & & & & & & \\
\hline 3.2.1.1a & $\begin{array}{l}\text { Alternate Action: Send request for } \\
\text { historical lab test result content to data } \\
\text { repository(ies) }\end{array}$ & 3.2.1.1a & $\begin{array}{l}\text { Alternate Action: Send request for } \\
\text { historical lab test result content to } \\
\text { data repository(ies) }\end{array}$ & 3.2.1.1a & $\begin{array}{l}\text { Alternate Action: Send request } \\
\text { for historical lab test result } \\
\text { content to data repository(ies) }\end{array}$ & LI8 & EHR request \\
\hline $3.2 .1 .1 \mathrm{~b}$ & $\begin{array}{l}\text { Alternate Action: Submit authentication } \\
\text { information to the data repository }\end{array}$ & & & & & & \\
\hline 3.2.1.2 & $\begin{array}{l}\text { Action: Confirm data integrity of } \\
\text { received results }\end{array}$ & & & & & & \\
\hline 3.2.1.3 & $\begin{array}{l}\text { Action: Parse and validate results } \\
\text { content }\end{array}$ & & & & & & \\
\hline 3.2.1.4 & Action: Merge data into EHR & & & & & & \\
\hline 3.2.1.5 & $\begin{array}{l}\text { Action: New results are flagged within } \\
\text { EHR }\end{array}$ & & & & & & \\
\hline 3.2.1.6 & $\begin{array}{l}\text { Action: Acknowledge receipt of lab } \\
\text { results }\end{array}$ & 3.2.1.6 & $\begin{array}{l}\text { Action: Acknowledge receipt of lab } \\
\text { results }\end{array}$ & 3.2.1.6 & $\begin{array}{l}\text { Action: Acknowledge receipt of } \\
\text { lab results }\end{array}$ & & \\
\hline 3.2.1.7 & Action: Log receipt of lab test results & & & & & & \\
\hline 3.2.1.7a & $\begin{array}{l}\text { Alternate Action: Produce exception } \\
\text { list of errors }\end{array}$ & & & & & & \\
\hline 3.2.2.0 & $\begin{array}{l}\text { Event: Receive notification of lab test } \\
\text { results }\end{array}$ & 3.2.2.0 & $\begin{array}{l}\text { Event: Receive notification of lab } \\
\text { test results }\end{array}$ & 3.2.2.0 & $\begin{array}{l}\text { Event: Receive notification of lab } \\
\text { test results }\end{array}$ & LI14 & lab result availability notification \\
\hline 3.2.2.1 & $\begin{array}{l}\text { Action: Receive notification that test } \\
\text { results are available }\end{array}$ & 3.2.2.1 & $\begin{array}{l}\text { Action: Receive notification that } \\
\text { test results are available }\end{array}$ & 3.2.2.1 & $\begin{array}{l}\text { Action: Receive notification that } \\
\text { test results are available }\end{array}$ & & \\
\hline
\end{tabular}




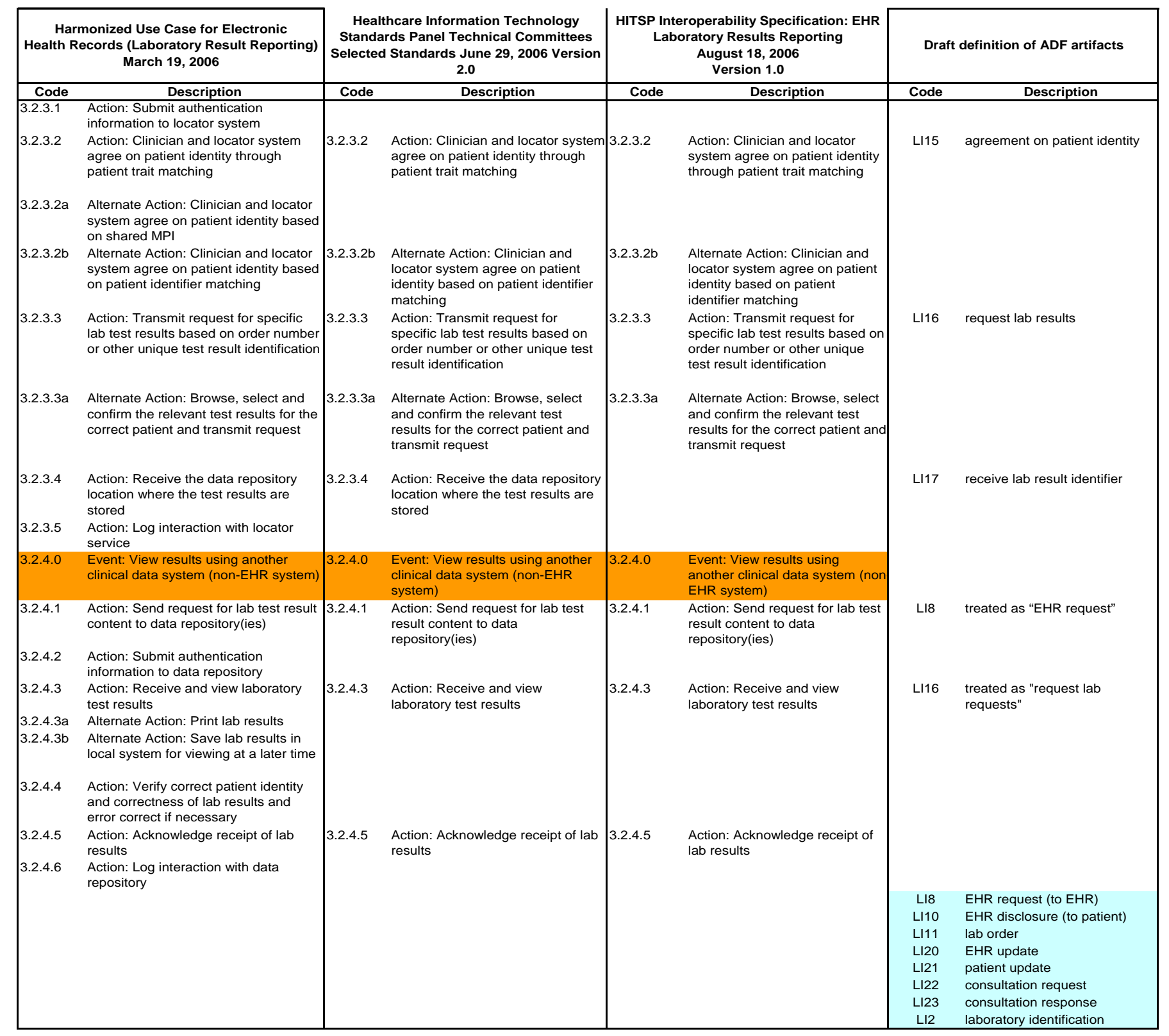




\begin{tabular}{|c|c|c|c|c|c|c|c|}
\hline \multicolumn{2}{|c|}{$\begin{array}{c}\text { Harmonized Use Case for Electronic } \\
\text { Health Records (Laboratory Result Reporting) } \\
\text { March 19, } 2006\end{array}$} & \multicolumn{2}{|c|}{$\begin{array}{c}\text { Healthcare Information Technology } \\
\text { Standards Panel Technical Committees } \\
\text { Selected Standards June 29, 2006 Version } \\
2.0\end{array}$} & \multicolumn{2}{|c|}{$\begin{array}{c}\text { HITSP Interoperability Specification: EHR } \\
\text { Laboratory Results Reporting } \\
\text { August } 18,2006 \\
\text { Version } 1.0\end{array}$} & \multicolumn{2}{|c|}{ Draft definition of ADF artifacts } \\
\hline Code & Description & Code & Description & Code & Description & Code & Description \\
\hline 3.3 .1 .1 & Action: Create test results & 3.3 .1 .1 & Action: Create test results & 3.3 .1 .1 & Action: Create test results & & \\
\hline \multirow[t]{2}{*}{ 3.3.1.2 } & Action: Send results to data repository & 3.3.1.2 & $\begin{array}{l}\text { Action: Send results to data } \\
\text { repository }\end{array}$ & 3.3.1.2 & $\begin{array}{l}\text { Action: Send results to data } \\
\text { repository }\end{array}$ & LI13 & send lab results (to repository) \\
\hline & & & & & & LI3 & repository identification \\
\hline 3.3.1.3 & Action: Log creation of test results & & & & & & \\
\hline 3.4.1.0 & Event: Store laboratory results & 3.4.1.0 & Event: Store laboratory results & 3.4.1.0 & Event: Store laboratory results & & \\
\hline 3.4.1.1 & $\begin{array}{l}\text { Action: Receive test results from } \\
\text { laboratory }\end{array}$ & & & & & & \\
\hline 3.4.1.2 & $\begin{array}{l}\text { Action: Verify authenticity of laboratory } \\
\text { and lab test result file contents }\end{array}$ & & & & & & \\
\hline 3.4.1.3 & $\begin{array}{l}\text { Action: Acknowledge receipt of test lab } \\
\text { results }\end{array}$ & 3.4.1.3 & $\begin{array}{l}\text { Action: Acknowledge receipt of test } \\
\text { lab results }\end{array}$ & 3.4.1.3 & $\begin{array}{l}\text { Action: Acknowledge receipt of } \\
\text { test lab results }\end{array}$ & & \\
\hline 3.4.1.4 & Action: Store test lab results & 3.4.1.4 & Action: Store test lab results & 3.4.1.4 & Action: Store test lab results & & \\
\hline 3.4.1.5 & $\begin{array}{l}\text { Action: Transmit lab test results to } \\
\text { ordering clinician and other providers } \\
\text { of care if appropriate }\end{array}$ & 3.4.1.5 & $\begin{array}{l}\text { Action: Transmit lab test results to } \\
\text { ordering clinician and other } \\
\text { providers of care if appropriate }\end{array}$ & 3.4.1.5 & $\begin{array}{l}\text { Action: Transmit lab test results } \\
\text { to ordering clinician and other } \\
\text { providers of care if appropriate }\end{array}$ & LI18 & send lab report \\
\hline 3.4.1.6 & $\begin{array}{l}\text { Action: Log receipt and storage of lab } \\
\text { test results }\end{array}$ & & & & & & \\
\hline 3.4.2.0 & $\begin{array}{l}\text { Event: Notify locator service of } \\
\text { laboratory results }\end{array}$ & 3.4.2.0 & $\begin{array}{l}\text { Event: Notify locator service of } \\
\text { laboratory results }\end{array}$ & 3.4.2.0 & $\begin{array}{l}\text { Event: Notify locator service of } \\
\text { laboratory results }\end{array}$ & & \\
\hline 3.4.2.1 & Action: Authenticate to locator service & & & & & & \\
\hline 3.4.2.2 & $\begin{array}{l}\text { Action: Send result location and } \\
\text { related information to locator service }\end{array}$ & 3.4 .2 .2 & $\begin{array}{l}\text { Action: Send result location and } \\
\text { related information to locator } \\
\text { service }\end{array}$ & 3.4 .2 .2 & $\begin{array}{l}\text { Action: Send result location and } \\
\text { related information to locator } \\
\text { service }\end{array}$ & LI19 & lab report to EHR \\
\hline 3.4.2.3 & $\begin{array}{l}\text { Action: Log interaction with locator } \\
\text { system }\end{array}$ & & & & & & \\
\hline 3.4.3.0 & $\begin{array}{l}\text { Event: Process Request for Laboratory } \\
\text { Test Results }\end{array}$ & 3.4.3.0 & $\begin{array}{l}\text { Event: Process Request for } \\
\text { Laboratory Test Results }\end{array}$ & 3.4.3.0 & $\begin{array}{l}\text { Event: Process Request for } \\
\text { Laboratory Test Results }\end{array}$ & & \\
\hline 3.4.3.1 & $\begin{array}{l}\text { Action: Receive and validate the query } \\
\text { request }\end{array}$ & 3.4.3.1 & $\begin{array}{l}\text { Action: Receive and validate the } \\
\text { query request }\end{array}$ & 3.4.3.1 & $\begin{array}{l}\text { Action: Receive and validate the } \\
\text { query request }\end{array}$ & & \\
\hline 3.4.3.2 & $\begin{array}{l}\text { Action: Authenticate and verify as } \\
\text { ordering clinician or provider of care }\end{array}$ & & & & & & \\
\hline 3.4.3.3 & $\begin{array}{l}\text { Action: Authorize release of laboratory } \\
\text { test results }\end{array}$ & & & & & & \\
\hline 3.4.3.4 & $\begin{array}{l}\text { Action: Transmit lab results of an } \\
\text { identified patient to an ordering } \\
\text { clinician or provider of care }\end{array}$ & 3.4.3.4 & $\begin{array}{l}\text { Action: Transmit lab results of an } \\
\text { identified patient to an ordering } \\
\text { clinician or provider of care }\end{array}$ & 3.4.3.4 & $\begin{array}{l}\text { Action: Transmit lab results of an } \\
\text { identified patient to an ordering } \\
\text { clinician or provider of care }\end{array}$ & LI18 & $\begin{array}{l}\text { send lab report (from } \\
\text { repository) }\end{array}$ \\
\hline 3.4.3.5 & Action: Log interaction & & & & & & \\
\hline
\end{tabular}




\begin{tabular}{|c|c|c|c|c|c|c|c|}
\hline \multicolumn{2}{|c|}{$\begin{array}{c}\text { Harmonized Use Case for Electronic } \\
\text { Health Records (Laboratory Result Reporting) } \\
\text { March 19, } 2006\end{array}$} & \multicolumn{2}{|c|}{$\begin{array}{c}\text { Healthcare Information Technology } \\
\text { Standards Panel Technical Committees } \\
\text { Selected Standards June 29, 2006 Version } \\
2.0\end{array}$} & \multicolumn{2}{|c|}{$\begin{array}{c}\text { HITSP Interoperability Specification: EHR } \\
\text { Laboratory Results Reporting } \\
\text { August } 18,2006 \\
\text { Version } 1.0\end{array}$} & \multicolumn{2}{|c|}{ Draft definition of ADF artifacts } \\
\hline Code & Description & Code & Description & Code & Description & Code & Description \\
\hline 3.5 .1 .1 & $\begin{array}{l}\text { Action: Receive test result (file) } \\
\text { location information and related } \\
\text { information }\end{array}$ & 3.5 .1 .1 & $\begin{array}{l}\text { Action: Receive test result (file) } \\
\text { location information and related } \\
\text { information }\end{array}$ & & & & \\
\hline 3.5.1.2 & $\begin{array}{l}\text { Action: Verify authenticity of lab test } \\
\text { result location and completeness of } \\
\text { related information }\end{array}$ & & & & & & \\
\hline 3.5.1.3 & $\begin{array}{l}\text { Action: Index test result by appropriate } \\
\text { patient and other indices }\end{array}$ & & & & & & \\
\hline 3.5.2.0 & $\begin{array}{l}\text { Event: Process query to provide } \\
\text { laboratory test result location(s) }\end{array}$ & 3.5.2.0 & $\begin{array}{l}\text { Event: Process query to provide } \\
\text { laboratory test result location(s) }\end{array}$ & 3.5.2.0 & $\begin{array}{l}\text { Event: Process query to provide } \\
\text { laboratory test result location(s) }\end{array}$ & & \\
\hline 3.5.2.1 & $\begin{array}{l}\text { Action: Authenticate clinician } \\
\text { requesting laboratory test results }\end{array}$ & & & & & & \\
\hline 3.5.2.2 & $\begin{array}{l}\text { Action: Clinician and locator system } \\
\text { agree on patient identity }\end{array}$ & 3.5.2.2 & $\begin{array}{l}\text { Action: Clinician and locator system } \\
\text { agree on patient identity }\end{array}$ & 3.5 .2 .2 & $\begin{array}{l}\text { Action: Clinician and locator } \\
\text { system agree on patient identity }\end{array}$ & LI15 & agreement on patient identity \\
\hline 3.5 .2 .3 & $\begin{array}{l}\text { Action: Receive request for lab test } \\
\text { results based on lab order number or } \\
\text { other unique lab test identifier }\end{array}$ & 3.5 .2 .3 & $\begin{array}{l}\text { Action: Receive request for lab test } \\
\text { results based on lab order number } \\
\text { or other unique lab test identifier }\end{array}$ & 3.5.2.3 & $\begin{array}{l}\text { Action: Receive request for lab } \\
\text { test results based on lab order } \\
\text { number or other unique lab test } \\
\text { identifier }\end{array}$ & LI25 & $\begin{array}{l}\text { lab report request (from care } \\
\text { provider to locator) }\end{array}$ \\
\hline $3.5 .2 .3 \mathrm{a}$ & $\begin{array}{l}\text { Alternate Action: Provide lab result } \\
\text { availability information based on } \\
\text { clinician query/browse }\end{array}$ & 3.5.2.3a & $\begin{array}{l}\text { Alternate Action: Provide lab result } \\
\text { availability information based on } \\
\text { clinician query/browse }\end{array}$ & $3.5 .2 .3 a$ & $\begin{array}{l}\text { Alternate Action: Provide lab } \\
\text { result availability information } \\
\text { based on clinician query/browse }\end{array}$ & & \\
\hline 3.5.2.4 & Action: Authorize data release & & & & & & \\
\hline 3.5 .2 .5 & $\begin{array}{l}\text { Action: Send lab result location (links) } \\
\text { pointers to authorized clinician. }\end{array}$ & 3.5.2.5 & $\begin{array}{l}\text { Action: Send lab result location } \\
\text { (links) pointers to authorized } \\
\text { clinician. }\end{array}$ & 3.5.2.5 & $\begin{array}{l}\text { Action: Send lab result location } \\
\text { (links) pointers to authorized } \\
\text { clinician. }\end{array}$ & LI17 & send lab result identifier \\
\hline 3.5.2.6 & Action: Log interaction with clinician & & & & & & \\
\hline 3.5.3.0 & $\begin{array}{l}\text { Event: Notify provider(s) of care of new } \\
\text { laboratory test results }\end{array}$ & 3.5 .3 .0 & $\begin{array}{l}\text { Event: Notify provider(s) of care of } \\
\text { new laboratory test results }\end{array}$ & 3.5.3.0 & $\begin{array}{l}\text { Event: Notify provider(s) of care } \\
\text { of new laboratory test results }\end{array}$ & LI24 & publish lab result availability \\
\hline 3.5 .3 .1 & Action: Send notification to clinician & 3.5 .3 .1 & Action: Send notification to clinician & 3.5 .3 .1 & $\begin{array}{l}\text { Action: Send notification to } \\
\text { clinician }\end{array}$ & $\begin{array}{l}\text { LI4 } \\
\text { LI9 }\end{array}$ & $\begin{array}{l}\text { EHR identification } \\
\text { EHR delivery }\end{array}$ \\
\hline
\end{tabular}




\section{Appendix C - Comparison of architectures}

The figures that follow show comparisons of the conceptual architectures presented in this report with the architectures shown in the NHIN contractors' presentations.

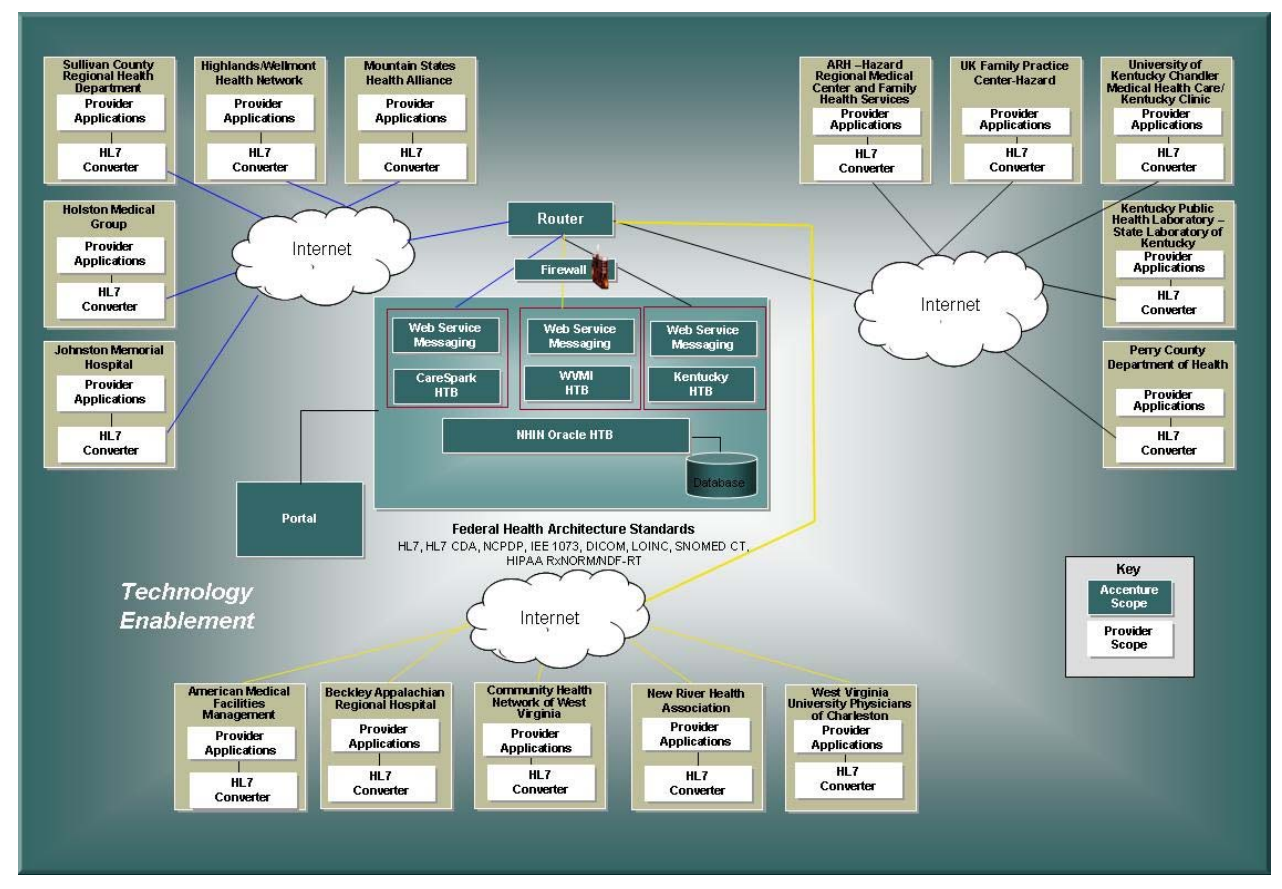

Figure C1a. Accenture architecture

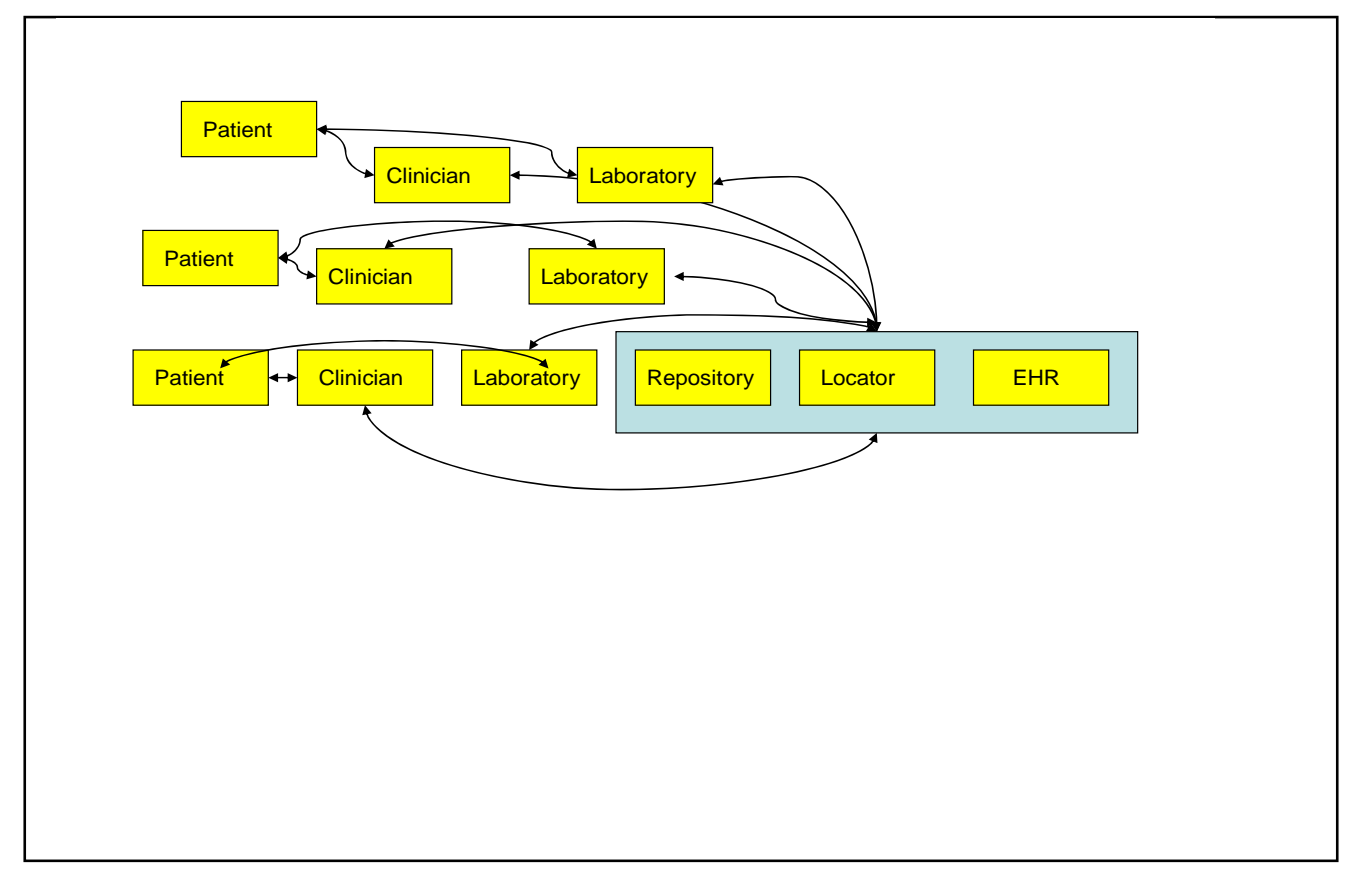

Figure C1b. ADF model of Accenture architecture 


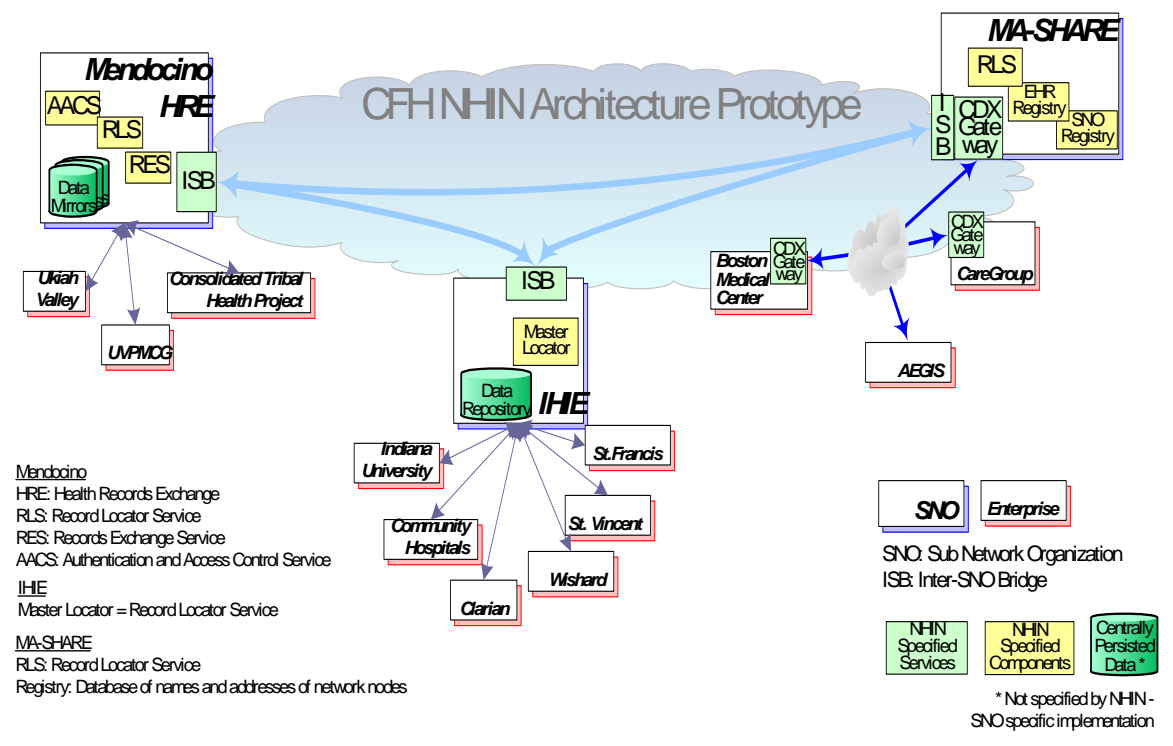

Figure C2a. CSC architecture

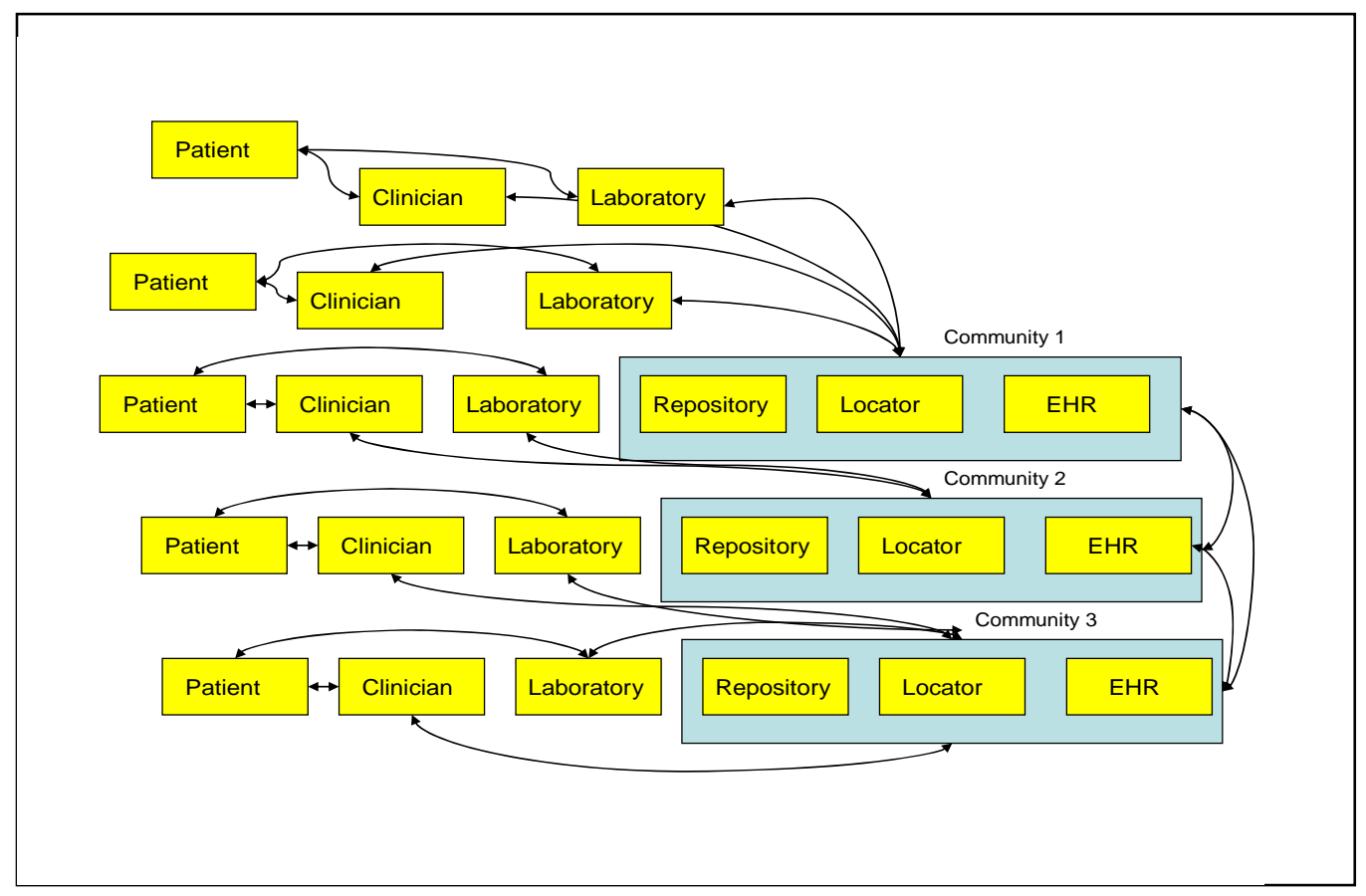

Figure C2b. ADF model of CSC architecture 


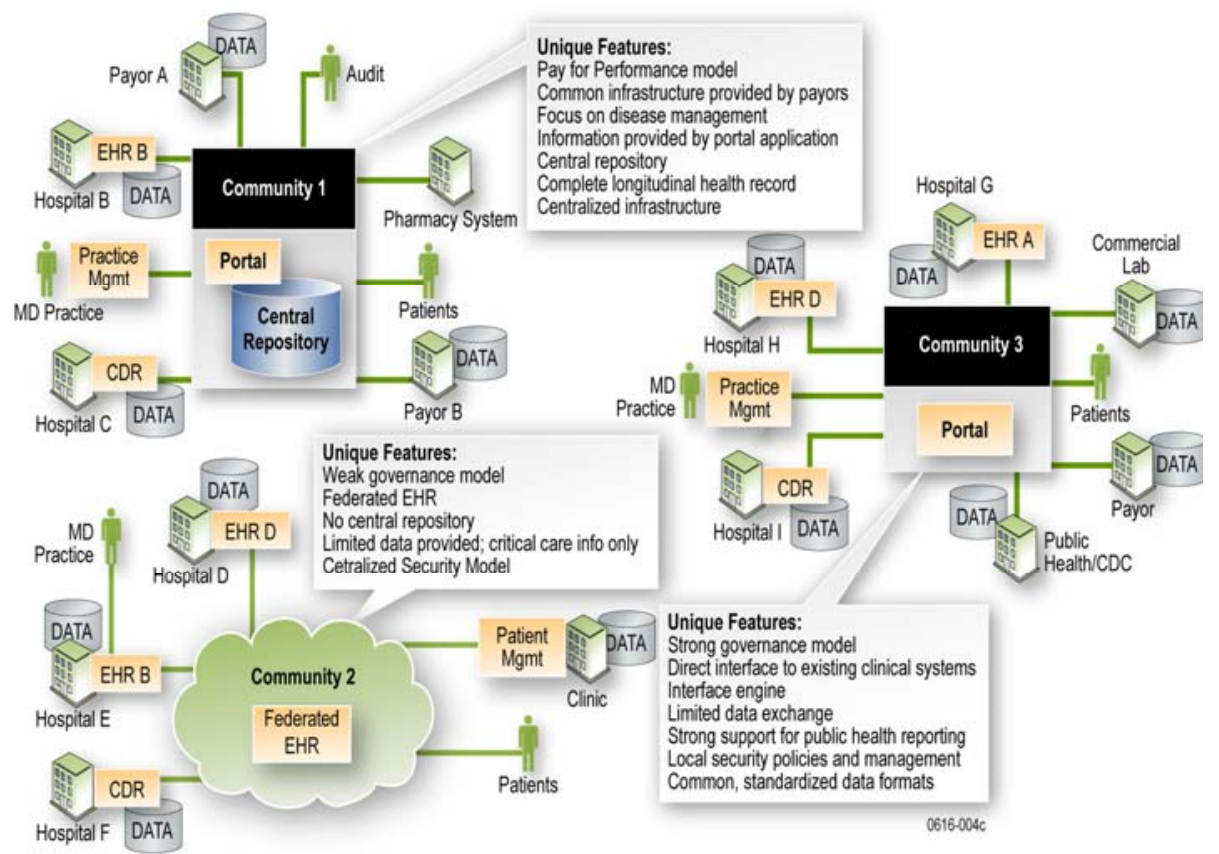

Figure CЗa. IBM architecture

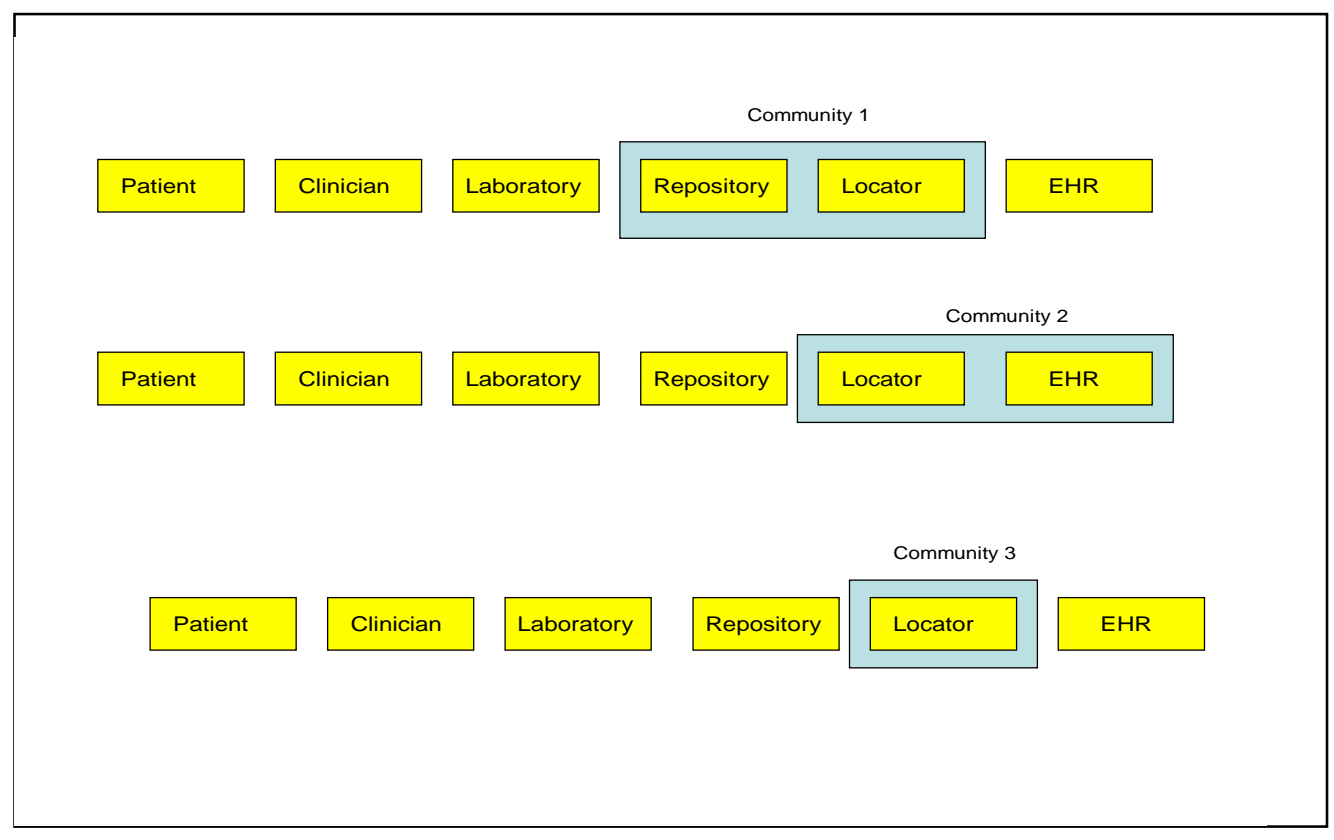

Figure C3b. ADF model of IBM architecture

(for clarity, links between services are not shown) 


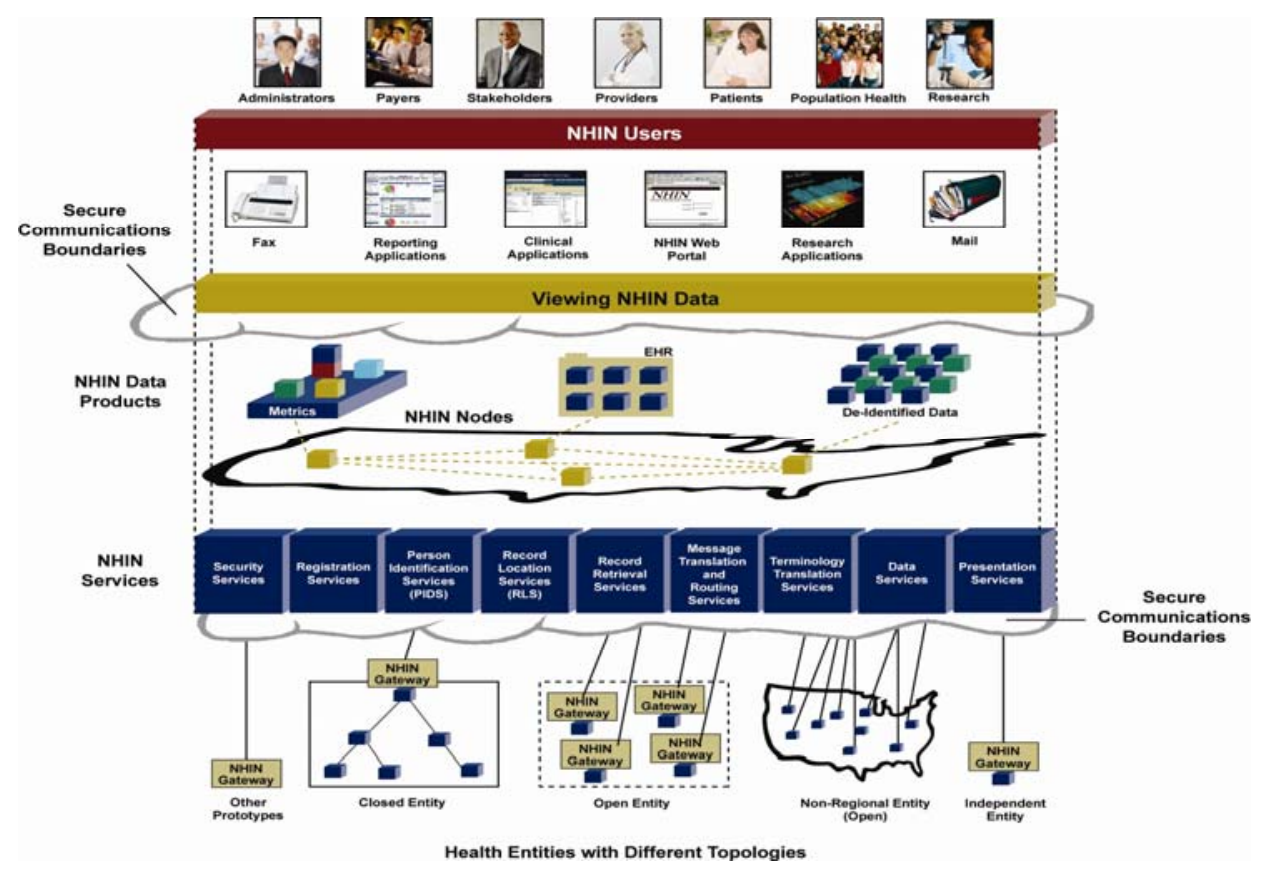

Figure C4a. Northrop Grumman architecture

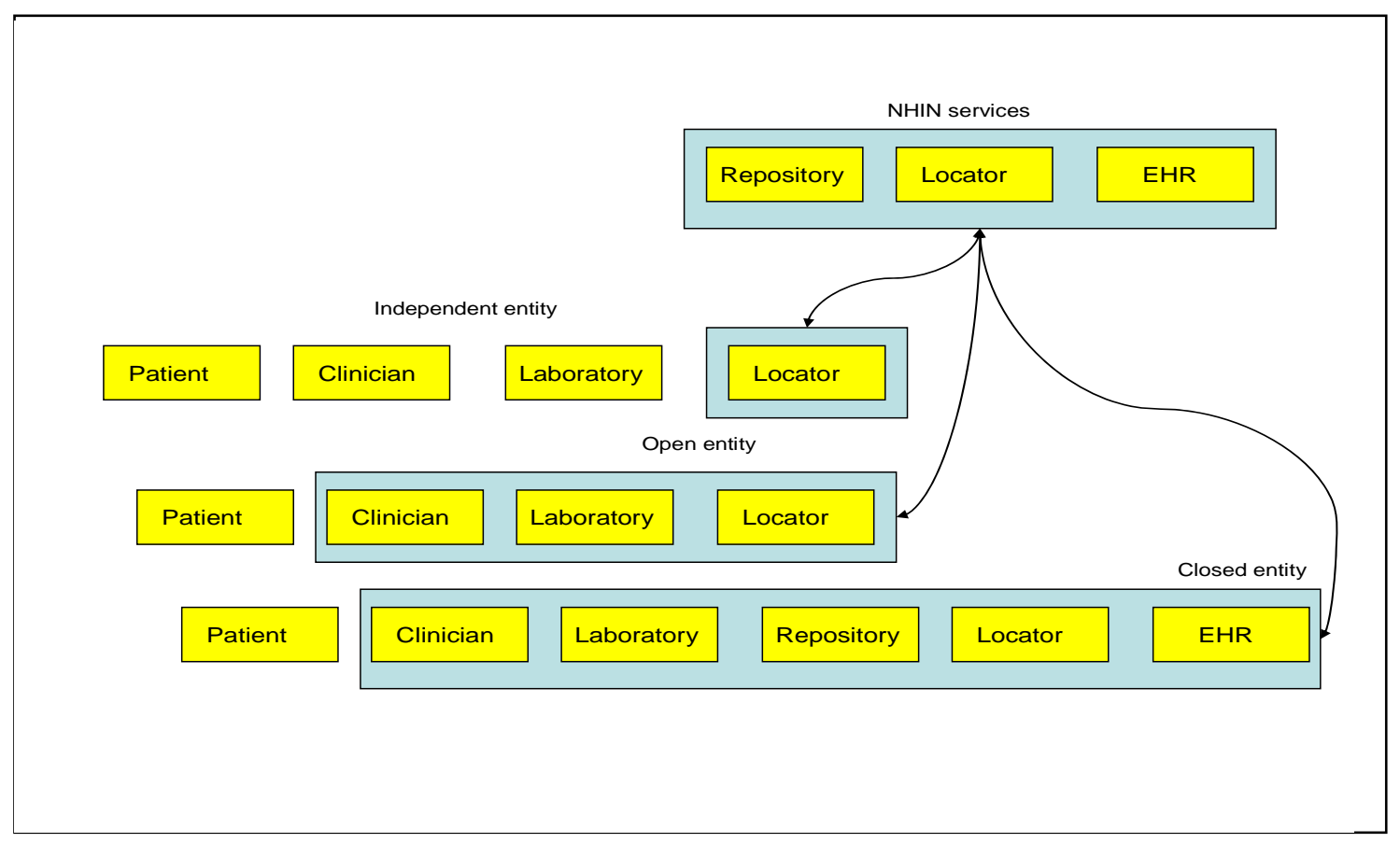

Figure C4b. ADF model of Northrop Grumman architecture (for clarity, links between services within entities are not shown) 